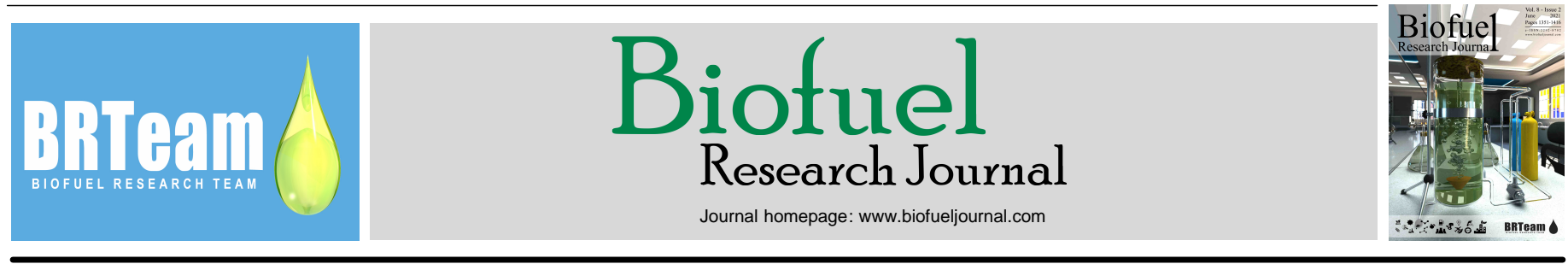

Original Research Paper

\title{
Comparison of acetone-butanol-ethanol fermentation and ethanol catalytic upgrading as pathways for butanol production: A techno-economic and environmental assessment
}

\author{
Estefanny Carmona-Garcia ${ }^{1}$, Paula Andrea Marín-Valencia ${ }^{1}$, Juan Camilo Solarte-Toro ${ }^{1}$, Konstantinos Moustakas ${ }^{2}$, Carlos \\ Ariel Cardona-Alzate ${ }^{1, *}$ \\ ${ }^{1}$ Universidad Nacional de Colombia sede Manizales, Instituto de Biotecnología y Agroindustria, Laboratorio de Equilibrios Químicos y Cinética Enzimática, \\ Departamento de Ingeniería Química, Manizales, Colombia. \\ ${ }^{2}$ School of Chemical Engineering, National Technical University of Athens, 9 Iroon Polytechniou Str., Zographou Campus, GR-15780, Athens, Greece.
}

\section{HIGHLIGHTS}

$>$ ABE fermentation showed a better economic performance than catalytic ethanol upgrading. $>$ Hydroxyapatite was selected as the best catalyst to upgraded ethanol.

$>\mathrm{ABE}$ fermentation was found a more sustainable process environmentally than catalytic ethanol upgrading.

$>$ Improved kinetic models to describe the catalytic upgrading of ethanol are needed.

\section{GRAPHICAL ABSTRACT}

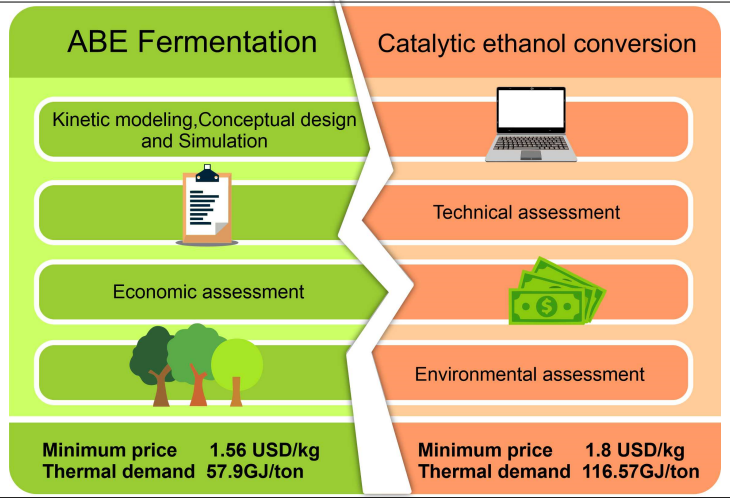

\section{ARTICLE INFO}

\section{Article history:}

Received 8 December 2020

Received in revised form 1 April 2021

Accepted 4 April 2021

Available online 1 June 2021

\section{Keywords:}

ABE fermentation

Catalytic ethanol upgrading

Butanol

Sugar platform

Lignocellulosic biomass

Economic analysis

\begin{abstract}
Butanol is an important compound used as a building block for producing value-added products and an energy carrier. The main butanol production pathways are conventional acetone-butanol-ethanol (ABE) fermentation and catalytic upgrading of ethanol. On the other hand, the application of biomass as a promising substrate for biofuel production has been widely considered recently. However, few studies have compared different butanol production pathways using biomass as raw material. In light of that, the present work aims (i) to provide a short review of the catalytic ethanol upgrading and (ii) to compare conventional ABE fermentation and catalytic ethanol upgrading processes from the economic and environmental perspectives. Aspen Plus v9.0 was used to simulate both processes. The economic and environmental assessments were carried out considering the Colombian economic context, a gate-to-gate approach, and single impact categories. Considering a processing scale of 1000 ton/d, the conventional $\mathrm{ABE}$ fermentation process presented a more favorable technical, economic, and environmental performance for butanol production from biomass. It also offered lower net energy consumption (i.e., $57.9 \mathrm{GJ} /$ ton of butanol) and higher butanol production (i.e., 2.59 ton/h). Nevertheless, the proposed processing scale was insufficient to reach economic feasibility for both processes. To overcome this challenge, the minimum processing scale had to be higher than 1584 ton/d and 1920 ton/d for conventional ABE fermentation and catalytic ethanol upgrading, respectively. Another critical factor in enhancing the economic feasibility of both butanol production pathways was the minimum selling price of butanol. More specifically, prices higher than $1.56 \mathrm{USD} / \mathrm{kg}$ and $1.80 \mathrm{USD} / \mathrm{kg}$ would be required for conventional ABE fermentation and catalytic ethanol upgrading, respectively. From the environmental impact point of view, the conventional ABE fermentation process led to a lower potential environmental impact than catalytic ethanol upgrading $(0.12 \mathrm{PEI} / \mathrm{kg} v s .0 .18 \mathrm{PEI} / \mathrm{kg}$, respectively).
\end{abstract}

(C) 2021 BRTeam. All rights reserved.

* Corresponding author at: Tel.: +57 68879300

E-mail address: ccardonaal@ unal.edu.co

Please cite this article as: Carmona-Garcia E., Marín-Valencia P.A., Solarte-Toro J.C., Moustakas K., Cardona-Alzate C.A. Comparison of ABE fermentation and ethanol catalytic upgrading as pathways for butanol production: A techno-economic and environmental assessment. Biofuel Research Journal 30 (2021) 1384-1399. DOI: 10.18331/BRJ2021.8.2.4 


\section{Contents}

1. Introduction.

Materials and Methods.

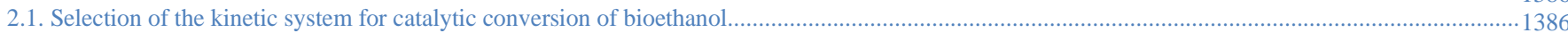

2.2. Simulation procedure

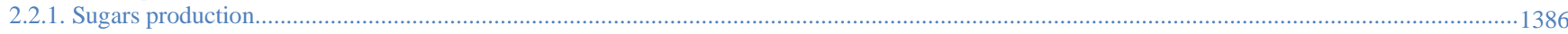

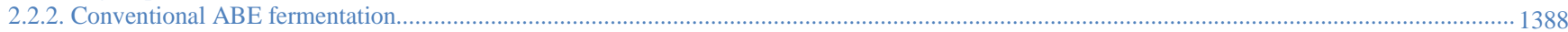

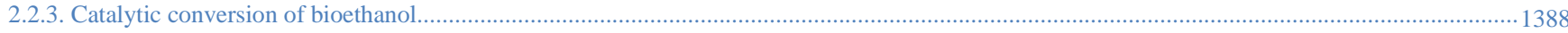

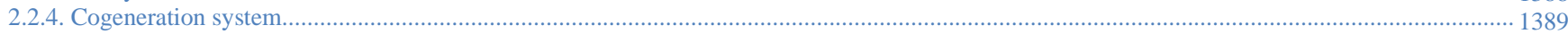

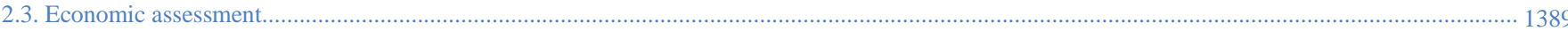

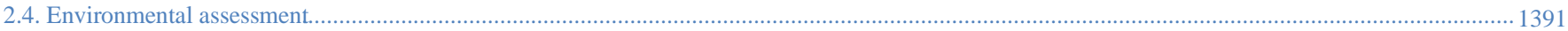

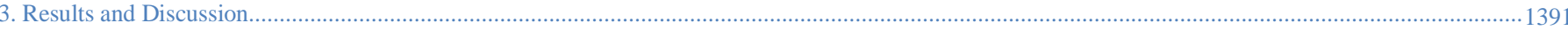

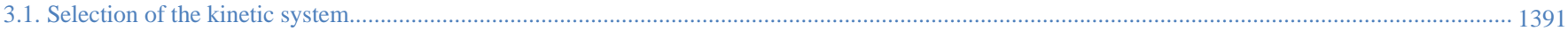

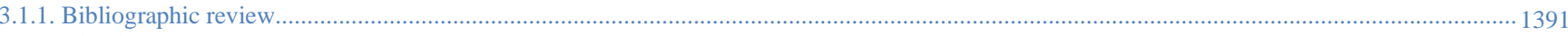

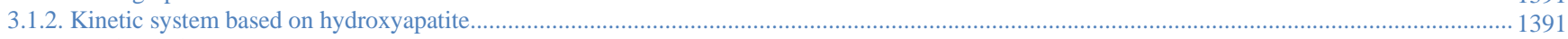

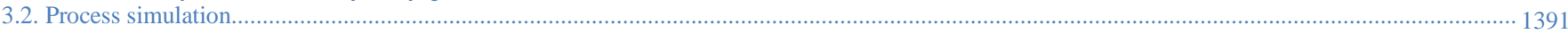

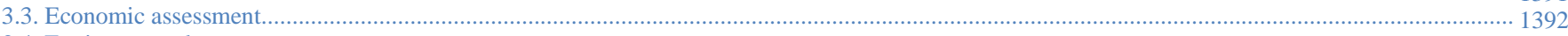

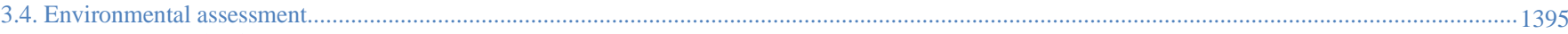

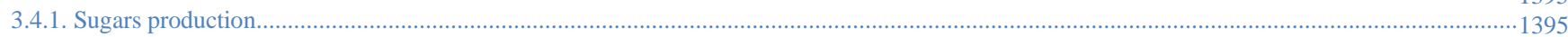

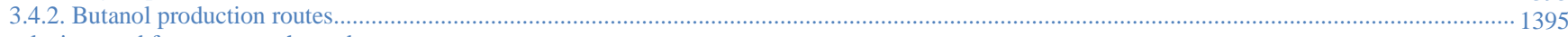

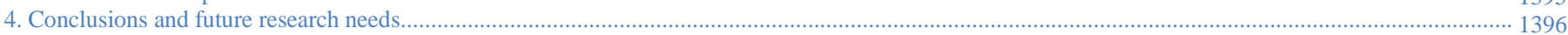

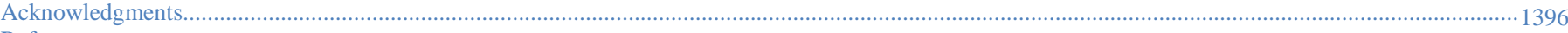

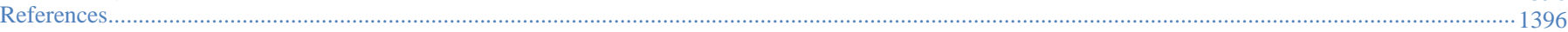

\begin{tabular}{|ll|}
\multicolumn{2}{l}{ Abbreviations } \\
ABE & Acetone - Butanol - Ethanol \\
BIGCC & Biomass integrated gasification combined cycle \\
CAPEX & Capital expenditures \\
CCS & Coffee cut stems \\
HAP & Hydroxyapatite \\
HMF & Hydroxyl-methyl-furfural \\
MPSEF & Minimum processing scale for economic feasibility \\
MSP & Minimum selling price \\
NPV & Net present value \\
OPEX & Operational expenditures \\
OPW & Orange peel waste \\
PEI & Potential environmental impact \\
RM & Raw material \\
VOC & Volatile organic compounds \\
WAR & Waste reduction \\
\hline
\end{tabular}

\section{Introduction}

Butanol is a four-carbon alcohol and a colorless liquid miscible with most organic solvents applied in the chemical industry (Lee et al., 2008). The molecular formula of this organic compound is $\mathrm{C}_{4} \mathrm{H}_{9} \mathrm{OH}$ with a molecular weight of $74.12 \mathrm{~g} / \mathrm{mol}$. Butanol is used as a solvent, intermediate, or raw material in the chemical industry to obtain a wide variety of value-added products (Fig. 1). About $50 \%$ of the world`s butanol is used to produce butyl acrylate and methacrylate esters (DOW, 2013). Other products derived from butanol are detergents, cosmetics, plasticizers, vitamins, amino resins, and butyl acetates. Besides, butanol has been applied as a solvent to produce lacquers, dyes, and rubber (Kumar and Gayen, 2011). In addition to the applications in chemical and textile industries, butanol has been proposed as a fuel or fuel additive because this organic compound has better combustion properties than ethanol (e.g., lower greenhouse gas emissions and higher octane number).

Alcohols have been proposed as biofuels because these compounds can provide higher oxygen contents, increase the heat of evaporation, reduce particulate matter release, and decrease $\mathrm{NO}_{\mathrm{x}}$ emissions. Methanol and ethanol have been the most studied alcohols as alternative fuels in internal combustion engines (Zhu et al., 2010). However, butanol has been profiled as a more promising biofuel owing to the mentioned advantages over methanol, ethanol, and gasoline. Global butanol production has been estimated at around 25 million metric tons per year (Mohapatra et al., 2020). On the other hand, the butanol market has been estimated to grow more than 30\% from 2017 to 2022
(Markets, 2016). Thus, butanol production is going to be one of the most studied processes in the following years. There are different routes to produce butanol. Nevertheless, the two most important pathways to obtain this organic compound are (i) via acetone-butanol-ethanol (ABE) fermentation from biomass and glucose and (ii) catalytic conversion of ethanol.

The ABE fermentation produces a mixture of acetone, butanol, and ethanol simultaneously from glucose using Clostridium strains (Qureshi e al., 2007). The butanol obtained via ABE fermentation is also known as biobutanol since the raw material used in this process is biomass. The most studied raw materials in $\mathrm{ABE}$ fermentation are lignocellulosic biomass (e.g., sugarcane bagasse) and agro-industrial residues (e.g., milk whey and molasses). These raw materials are preferred over first-generation raw materials (e.g., maize) as they do not contribute to the existing food $v s$. fuel conflict. Moreover, the application of agro-industrial residues use could reduce the environmental impacts associated with the improper disposal of these waste streams (Mussatto et al., 2013; Kumar Mahapatra and Kumar, 2017).

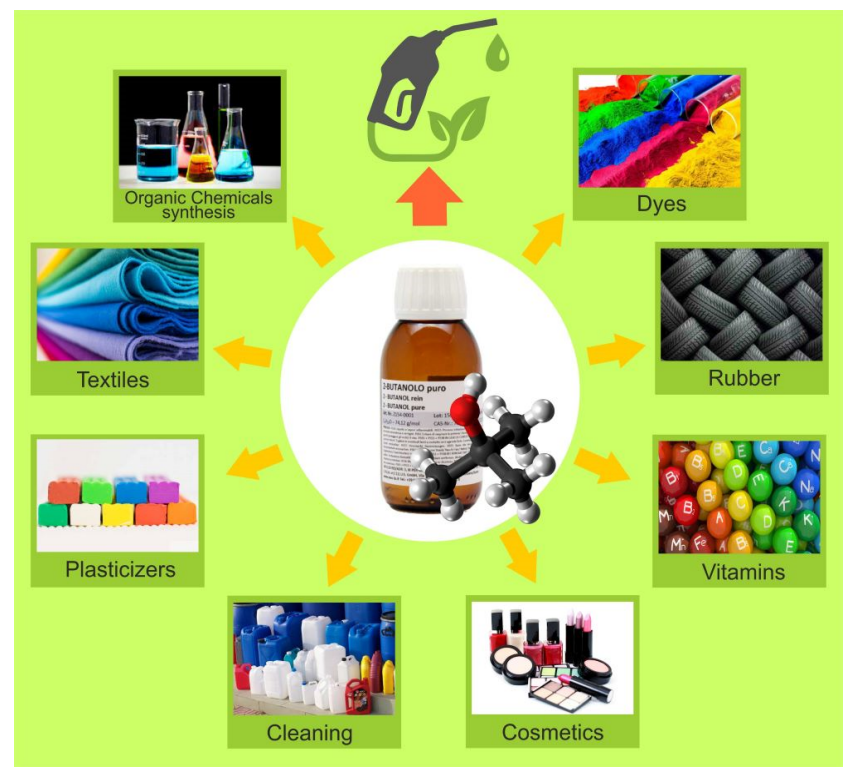

Fig. 1. Primary uses of butanol. 
Nevertheless, before lignocellulosic biomass can be used for butanol production, it should undergo costly processing, i.e., pretreatment and enzymatic hydrolysis to produce monomeric sugars (e.g., glucose and xylose) (Salehi Jouzani and Taherzadeh, 2015).

On the other hand, recent efforts have been focused on developing efficient routes to obtain value-added products from bioethanol. Conversion of ethanol into butanol using heterogeneous catalysts such as mixed oxides, metallic oxides, and hydroxyapatite (HAP) has been among these efforts (Ogo et al., 2011; Carvalho et al., 2012; Ho et al., 2016). The relevant industrial process to increase the carbon number of an alcohol by coupling two molecules was developed by Marcel Guerbet in the 1890s, thus known as the Guerbet reaction (Koda et al., 2009). The most commonly accepted path includes three types of reactions: (i) dehydrogenation, (ii) aldol condensation, and (iii) hydrogenation. Figure 2 shows the general mechanism to obtain butanol from ethanol. Koda et al. (2009) reported on ethanol upgrading at $120^{\circ} \mathrm{C}$ using homogeneous catalysts in a liquid phase, like iridium, sodium ethoxide, and 1,7-octadiene. These catalysts allowed to obtain 1-butanol with $51 \%$ of selectivity and $21 \%$ of yield. Other assays carried out in the gas phase and applying heterogeneous catalysts have also been reported in the existing literature. For instance, Ndaba et al. (2015) used MgO, Carvalho et al. (2012) used Mg-Al mixed oxides, and Ho et al. (2016) used Ca-P HAP.All these processes were performed at relatively high temperatures, between 300 and $450^{\circ} \mathrm{C}$. Among the mentioned catalysts, the Ca-P HAP presented the best selectivity to 1-butanol (i.e., 76\%) and an ethanol conversion (i.e., 15\%). Hence, HAP could be regarded as a promising catalyst to upgrade ethanol to butanol.

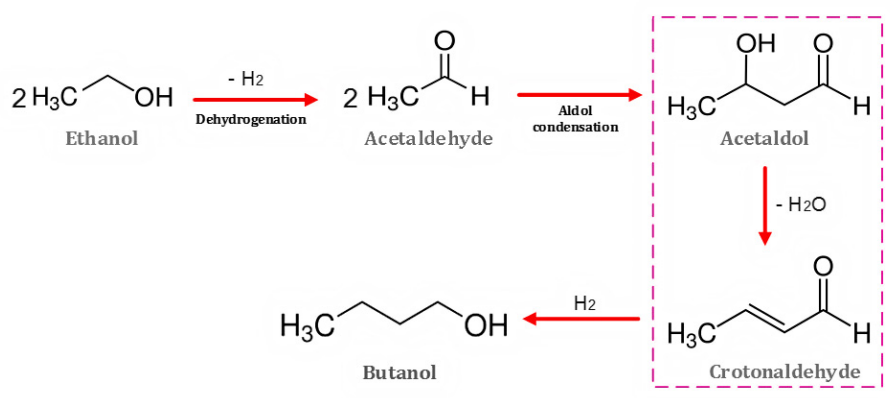

Fig. 2. Global reaction mechanism of butanol production from ethanol. Adapted from Ogo et al. (2011).

Despite the significance of the butanol production pathways, few studies have been focused on the techno-economic and environmental assessment of different butanol production pathways. Moreover, few studies have been devoted to model and understand catalytic ethanol upgrading using kinetic expressions. Thus, this works provides (i) a short literature review of the catalytic ethanol upgrading to butanol based on operating conditions, catalyst type, conversions, selectivity, and yields, (ii) a complete kinetic model to simulate the catalytic ethanol conversion to butanol as a function of the temperature, (iii) the mass and energy performance of two butanol technologies using lignocellulosic biomass as raw material, and (iv) a comparison of $\mathrm{ABE}$ fermentation and catalytic conversion in terms of economic and environmental aspects to find the best pathway to produce butanol.

\section{Materials and Methods}

\subsection{Selection of the kinetic system for catalytic conversion of bioethanol}

The catalytic routes to transform bioethanol into butanol are currently under dynamic research. The most common catalysts are those based on metals and HAP (Ogo et al., 2011). A literature review was carried out to analyze the best option, including catalysts, ethanol conversion, butanol selectivity, coproducts, and contact time. The kinetic model proposed by Tsuchida et al. (2006) was selected as one of the best to simulate the ethanol conversion into butanol. The main selection criterion of the model was the accuracy provided by the kinetic parameters and rate equations. Matlab R2013a (MathWorks, US) was used to solve a differential equations system in the present work. This calculation was done by applying the ode 45 function to obtain conversion and yield profiles of the process components.

The kinetic model was used to model the concentration profile of each product in the catalytic ethanol upgrading process. The modeling was done to understand the process and define operating variables such as temperature and residence time. Then, the yields obtained at the best conditions were used as input data in Aspen Plus v9.0. Besides, the use of these improved operating conditions offers the following advantages: (i) better estimation of the energy demand of the catalytic reactor, and (ii) more accurate equipment sizing.

\subsection{Simulation procedure}

As mentioned earlier, Aspen Plus software was used to develop the simulations. The Non-Random Two-Liquid (NRTL) thermodynamic model was chosen to describe the liquid phase (Gebreyohannes et al., 2014). The model provides a good representation of phase equilibria for highly nonideal systems (Prausnitz et al., 1999). For the vapor phase, the equation of state of Hayden-O'Connell was used due to the presence of carboxylic acids in the ABE fermentation process (i.e., butyric and acetic acid). The properties of lignin, hemicellulose, cellulose, biomass, and enzymes were taken from the NREL/MP-425-20685 "Development of an Aspen Plus Physical Property Database for Biofuels Components" (Wooley and Putsche, 1996). The energy requirements (i.e., utilities such as steam and cooling water) were determined using the Aspen Energy Analyzer v9.0 software. Besides, the raw materials mass flow in both processes was considered 1000 ton/d $(41.7$ ton/h).

\subsubsection{Sugars production}

This study was focused on the sugar platform obtained from lignocellulosic residues. For this case, the sugar platform was a dilute sugar stream (i.e., hydrolysate) with $40 \mathrm{~g} / \mathrm{L}$ of glucose concentration (approx.). This concentration value is a typical value obtained from lignocellulosic biomass after pretreatment and saccharification (Jafari et al., 2016). The selected raw materials were coffee cut stems (CCS) and orange peel waste (OPW). Both raw materials were selected based on three criteria; (i) annual production, (ii) supply chain and logistics, and (iii) potential applications at different scales. It should be noted that both CCS and OPW are agroresidues widely produced in Colombia after the harvesting and industrial use of coffee and orange, and amounted to 900 ton/d (AristizábalMarulanda et al., 2020) and 1320 ton/d (Ortiz-Sanchez et al., 2020) in 2019 , respectively. Thus, taking into account the first criterion, these raw materials can be considered potential feedstocks in medium and large-scale applications. Besides, both raw materials have a well-defined supply chain associated with the coffee crop renewal and orange juice extraction.

As for the second criterion (i.e., supply chain and logistics), CCS is a solid residue with relatively low moisture content and can be transported in trucks from farms to chemical facilities using the existing means of transport used for coffee grains. The CCS is usually left in the fields, with only $5 \%-10 \%$ used locally in the farms for cooking purposes. OPW is accumulated as residue produced by orange juice factories and is usually disposed of in landfills. Thus, this raw material could also benefit the existing means of transport used for landfill disposal (Ortiz et al., 2020). Finally, and as long as the third criterion is concerned, both proposed raw materials have been the subject of different studies to produce several value-added products and energy carriers in stand-alone processes or biorefineries due to the high sugar yields (Ortiz-Sanchez et al., 2020; Solarte-Toro et al., 2020). In Colombia, sugarcane bagasse is also a significant residue, meeting all the selection criteria laid forth above. However, this raw material is currently used as a fuel in the cogeneration systems of sugar mills, and thus was not considered in the present study. The sugar production simulations were performed to calculate the mass flow and production costs of this stage using the selected raw materials as feedstock. This procedure reduces the uncertainty associated with taking a single production cost as a reference. The sugar flows and average costs were included in the ABE simulation. For the catalytic upgrading process, bioethanol production (via fermentation) was considered using the flows and the average costs of dilute glucose production (via dilute acid 
pretreatment and saccharification). Subsequently, the obtained bioethanol was converted into butanol by catalytic conversion. Table 1 presents the chemical characterization of the selected raw materials used to simulate the sugar production process. According to the data tabulated in Table 1, both raw materials hold good potentials to recover sugars, especially glucose.

Table 1.

The chemical composition of coffee cut stems (CCS) and orange peel waste (OPW) considered in this study.

\begin{tabular}{lcc}
\hline Component & Coffee cut stems $(\% \mathbf{w} / \mathbf{w})$ & Orange peel waste (\% w/w, d.b.) \\
\hline Moisture & $4.053 \pm 4.053^{*}$ & - \\
Cellulose & $38.110 \pm 0.205$ & $28.887 \pm 6.250$ \\
Hemicellulose & $30.215 \pm 2.422$ & $10.233 \pm 0.836$ \\
Lignin & $14.906 \pm 7.456$ & $4.747 \pm 2.396$ \\
Extractives & $10.956 \pm 3.283$ & - \\
Ash & $1.759 \pm 0.783$ & $3.244 \pm 0.765$ \\
Soluble sugars & - & $19.164 \pm 5.061$ \\
Fat & - & $3.844 \pm 0.693$ \\
Protein & - & $6.444 \pm 1.761$ \\
Limonene & - & $4.311 \pm 0.625$ \\
Pectin & Average values of the data & $19.125 \pm 7.174$ \\
\hline & reported by García et al. (2017b) \\
Reference & and Quintero et al. (2013) & Ortiz-Sanchez et al. (2020); \\
\hline The standard deviations correspond to the deviations of each of the calculated averages.
\end{tabular}

\section{- Sugar platform from coffee cut stems}

The concise process flowsheet for producing sugars using CCS as raw material is presented in Figure 3. Initially, the raw material particle size was reduced until reaching $5 \mathrm{~mm}$ using a milling step. After the milling process, the feedstock was pretreated with dilute acid to remove hemicellulose (SolarteToro et al., 2019). The conditions chosen for the simulation procedure were: acid concentration of $2 \%(\mathrm{w} / \mathrm{v}), 2 \mathrm{bar}$, the temperature of $121^{\circ} \mathrm{C}, 15 \mathrm{~min}$ of residence time, and solid:liquid ratio of 1.5:10 (Quintero and Cardona, 2011). The pretreatment yields were calculated using the kinetic expressions reported by Esteghlalian et al. (1997) since CCS is considered woody biomass. A sugars stream rich in pentoses $\left(\mathrm{C}_{5}\right)$, and a spent solid fraction were obtained after the dilute acid pretreatment process. One of the disadvantages of acid pretreatment is the formation of soluble toxic compounds and inhibitors such as acetates, acids, and phenolic compounds (e.g., vanillic acid) (Sun and Liu, 2012). Hence, after the acid pretreatment, a detoxification and evaporation process would be needed to reduce the inhibitor concentration before the ABE fermentation process. Such a hydrolysate treatment allows removing $100 \%, 99.9 \%$, and $57.9 \%$ of acetic acid, hydroxyl-methyl-furfural (HMF), and phenolic compounds, respectively (Lu et al., 2013). Nevertheless, the liquid fraction (rich in xylose) was not considered to produce butanol since the implementation of the process mentioned above increases the capital and operating costs. Even so, this stream could be used to generate value-added products such as furfural (Aristizábal-Marulanda. et al., 2015).

After the pretreatment stage, the solid fracti on rich in cellulose was sent to the saccharification stage, where a commercial cellulase enzyme was used. The enzyme loading was $20.7 \mathrm{mg}$ protein/g cellulose (Liu et al., 2016). The operating conditions of the saccharification process were (i) temperature of $50^{\circ} \mathrm{C}$, (ii) solid:liquid ratio of $1.5: 10$, (iii) residence time of $50 \mathrm{~h}$, and (iv) agitation speed of $120 \mathrm{rpm}$ (Humbird et al., 2011). The saccharification process was simulated stoichiometrically based on the results reported by Quintero et al. (2013). This stage produced a hexosesrich (i.e., glucose) liquor and a solid rich in lignin. The liquid fraction was sent to sterilization $\left(121^{\circ} \mathrm{C}\right)$ to inactivate enzymes and other biological activities ( $\mathrm{Li}$ et al., 2014). Finally, the hydrolysate rich in glucose was cooled to $37^{\circ} \mathrm{C}$, reaching suitable conditions for fermentation.

\section{- Sugar platform from orange peel waste}

The simplified process flowsheet for producing the sugar platform from OPW is presented in Figure 4. In the same way as CCS, the raw material particle size was reduced through a milling step. Then, steam explosion pretreatment was used to remove limonene and hemicellulose from OPW (Tomás-Pejó et al., 2008). The conditions chosen for the steam explosion simulation were: solids concentration of approximately $10 \%(\mathrm{w} / \mathrm{v})$, direct injection of steam at $150^{\circ} \mathrm{C}$, and pressure of $10 \mathrm{bar}$ for $10 \mathrm{~min}$ (Forgács et al., 2012). Then, the treated slurry was discharged into an expansion tank (1 bar). This sudden reduction of the pressure caused disruption of citrus peel structure, leading to the extraction of some compounds (e.g., limonene, sugars) (Wilkins et al., 2007). The pretreatment yields were calculated based on the literature (Zhou et al., 2008; Boluda-Aguilar et al., 2010; Forgács et al., 2012). Besides, 40\% w/w of total hemicellulosic fraction solubilization was considered (Boluda-Aguilar and López-Gómez, 2013).

The solid fraction was rich in cellulose and pectin. Thus, a simultaneous saccharification process would lead to a high yield of fermentable sugars (Kuo et al., 2019). For this, pectinase and cellulose loadings of $1163 \mathrm{IU} / \mathrm{g}$ dry peel and $0.24 \mathrm{FPU} / \mathrm{g}$ dry peel were used, respectively (Pourbafrani et al., 2007). The operating conditions were (i) temperature of $45^{\circ} \mathrm{C}$, (ii) residence time of $50 \mathrm{~h}$, (iii) agitation speed of $120 \mathrm{rpm}$, and (iv) solid concentration of $80 \mathrm{~g} / \mathrm{L}$ (Talebnia et al., 2008). The enzymatic hydrolysis was simulated stoichiometrically considering cellulose and pectin conversion into glucose and galacturonic acid, respectively (Pourbafrani et al., 2007). The liquid fraction (rich in glucose and galacturonic acid) was sent to sterilization $\left(121^{\circ} \mathrm{C}\right.$ ) (Kumar and Gayen, 2011). Finally, the hydrolysate was cooled to $37^{\circ} \mathrm{C}$. It should be noted that no inhibition has been associated with the presence of galacturonic acid in ABE or ethanol fermentation. In both sugar production processes, the xylose-rich streams were not considered to be used as a substrate in the $\mathrm{ABE}$ fermentation

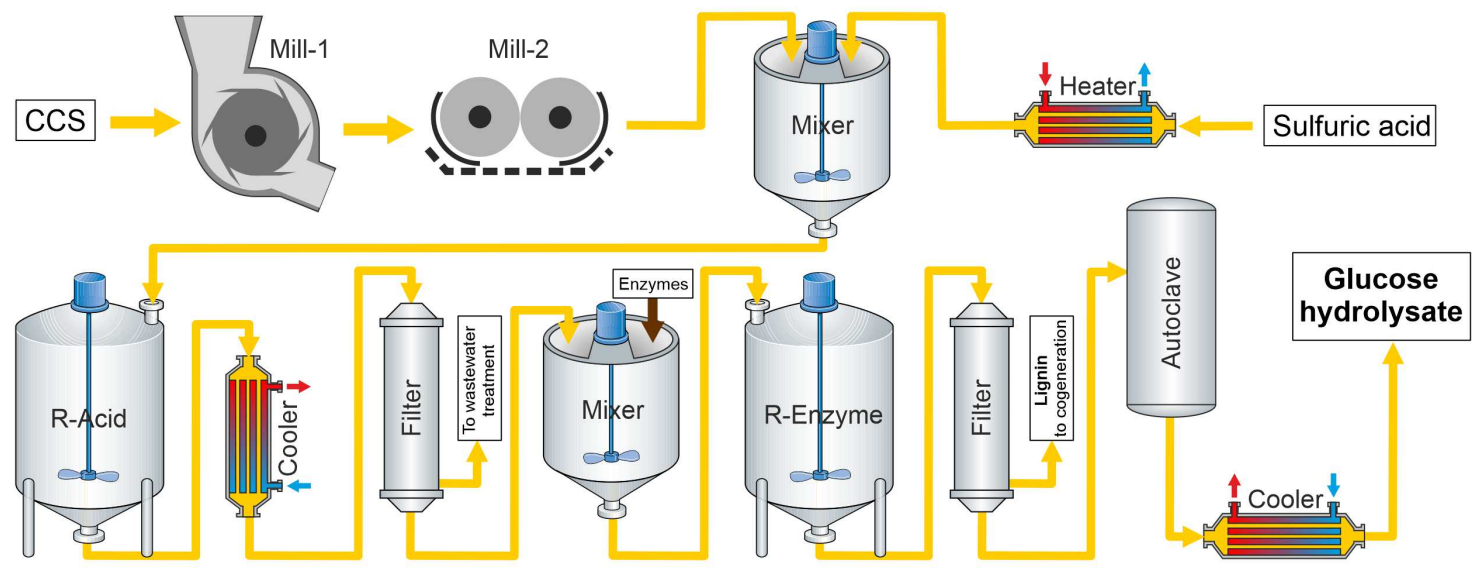

Fig. 3. Process flow diagram of the sugar platform production from coffee cut stems (CCS). 


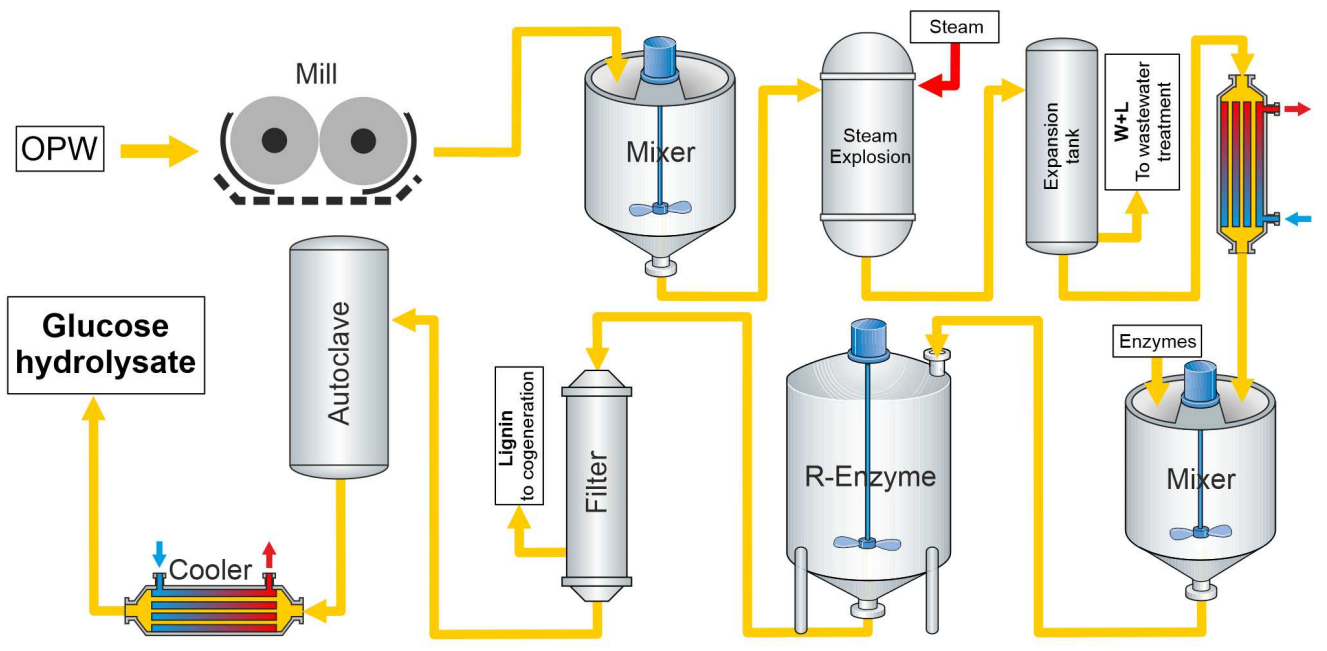

Fig. 4. Process flow diagram of the sugar platform production from orange peel waste (OPW) (W+L: water+limonene).

process since pentoses have not been categorized as a suitable carbon source for Clostridium acetobutylicum (Xin et al., 2014). For example, Gu et al. (2009) demonstrated that this strain consumed $86 \%$ glucose and only $6 \%$ xylose.

\subsubsection{Conventional ABE fermentation}

The process flow diagram of the conventional ABE fermentation process is presented in Figure 5. The glucose-rich streams from CCS or OPW were the inlet stream in the $\mathrm{ABE}$ fermentation process. The reactor was inoculated with $10 \%$ of the total volume and incubat ed at $37^{\circ} \mathrm{C}$. The fermentation process was simulated considering a residence time of $70 \mathrm{~h}$. The product yields were taken from studies using $C$. acetobutylicum and similar substrate conditions: 0.35 $\mathrm{g}_{\mathrm{ABE}} / \mathrm{g}_{\text {glucose }}$ and $0.24 \mathrm{~g}_{\text {butanol }} / \mathrm{g}_{\text {glucose }}$ (Abdul Razak et al., 2013; Al-Shorgani et al., 2016). After the fermentation stage, cell biomass was separated from the culture broth using a plate and frame filter. The solid was sent to the cogeneration stage. The conventional ABE fermentation process consisted of a typical fermentation process and a series of distillation columns (Mariano et al., 2013).
The simulation of the distillation columns was carried out in a rigorous way using the results obtained by applying the Fenske-UnderwoodGilliland equations as input data. The short-cut method results were obtained using the Distillati on Tower Winn-Underwood-Gilliland (DSTW) model, and the rigorous distillation was done using the RadFrac model in Aspen Plus v.9.0. The culture broth contained approximately 1$2 \%(\mathrm{w} / \mathrm{w})$ of ABE. Thus, four distillation towers and a decanter were needed to obtain butanol at $99.5 \% \mathrm{w} / \mathrm{w}$, acetone at $99.5 \% \mathrm{w} / \mathrm{w}$, and ethanol at $70 \% \mathrm{w} / \mathrm{w}$.

\subsubsection{Catalytic conversion of bioethanol}

The catalytic conversion of ethanol was performed using HAP as the catalyst. Before the catalytic production of butanol, ethanol production using the hydrolysate of CCS or OPW was also considered. Figure 6 shows the complete flowsheet for the catalytic conversion of ethanol. The hydrolysate obtained from CCS or OPW was the input for the fermentation

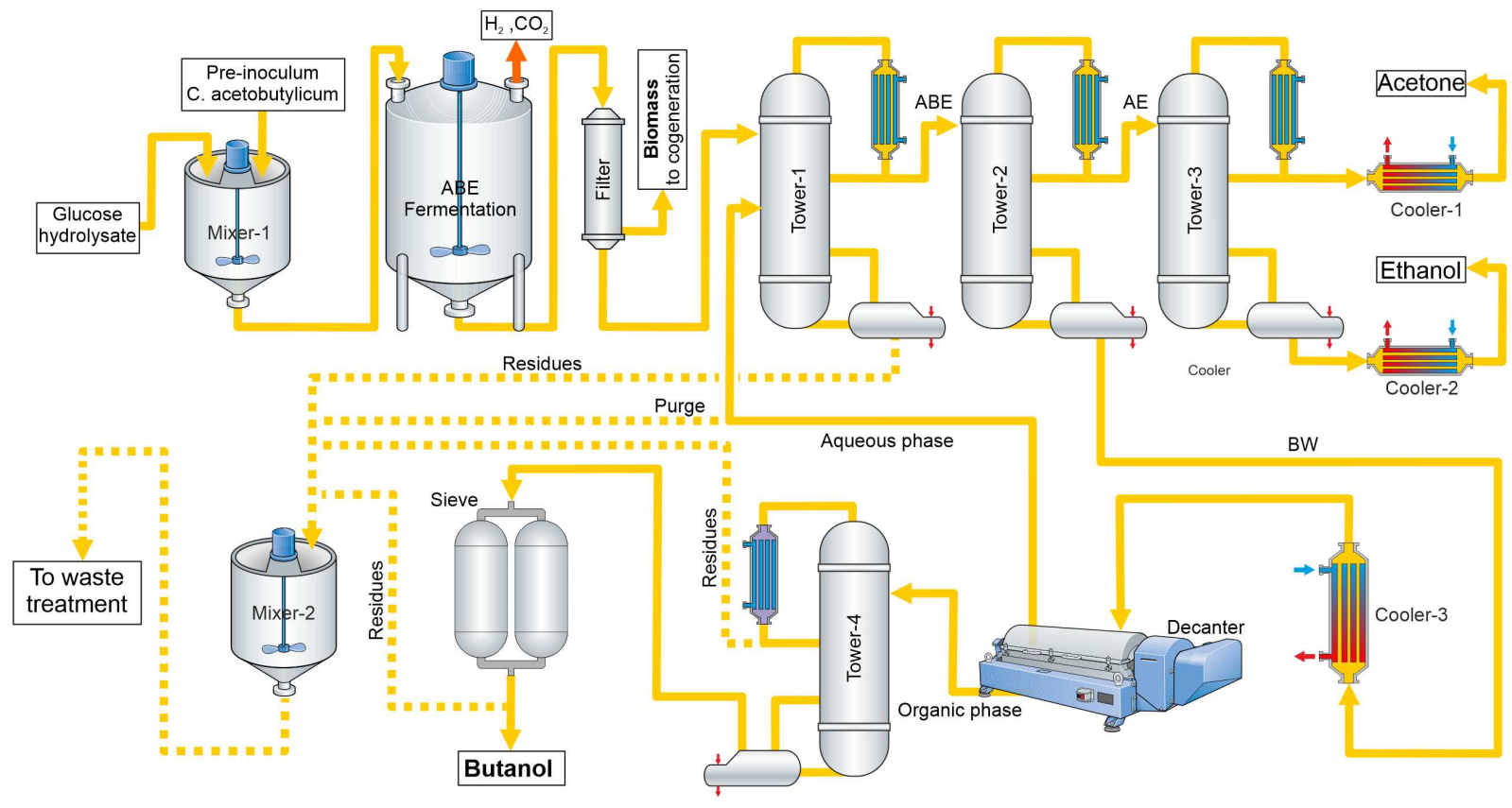

Fig. 5. Process flow diagram of the conventional ABE fermentation using glucose obtained from lignocellulosic biomass as substrate. 


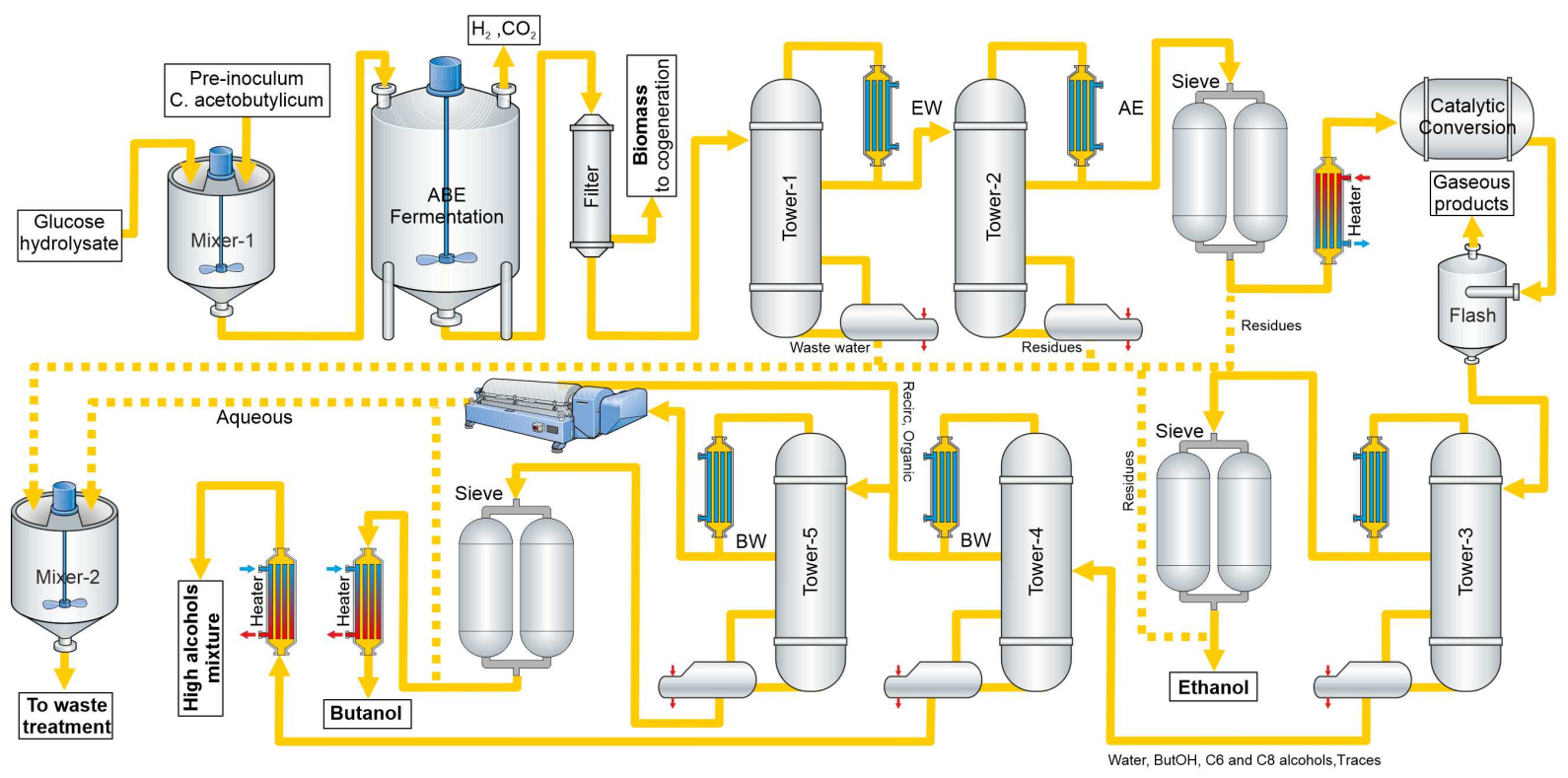

Fig. 6. Process flow diagram of the ethanol catalytic conversion using glucose obtained from the proposed raw materials.

process. Fermentation time was assumed in $36 \mathrm{~h}$. The reactor was inoculated with $10 \%$ of the total volume and incubated at $32^{\circ} \mathrm{C}$. In production facilities, ethanol yields typically reach $80-90 \%$ of the theoretical yield (i.e., $0.51 \mathrm{~g} / \mathrm{g}$ sugar) (Zhou et al., 2007). In this case, a value of $95 \%$ was considered. After the fermentation stage, cell biomass was separated from the culture broth, and the solid was sent to the cogeneration stage. The fermentation broth or "beer" with an ethanol concentration of $4-7 \%(\mathrm{w} / \mathrm{w})$ was sent to a separation section, including two distillation columns and molecular sieves. After the separation, ethanol at $99.6 \% \mathrm{w} / \mathrm{w}$ was obtained. The ethanol purification is essential since the catalytic process is limited by equilibrium or catalyst deactivation due to water presence. The industrial data to design the ethanol catalytic conversion are not yet available. Thus, the design of this process was carried out according to the data reported in the existing literature. Fresh ethanol was preheated to the reaction temperature of $350^{\circ} \mathrm{C}$ in a heat exchanger. A fixed-packed-bed reactor (PBR) with HAP and a weight-flow ratio of $130 \mathrm{~h} \mathrm{~g}_{\text {catalyst }} / \mathrm{mol}$ ethanol was simulated (Ogo et al., 2011). Initially, ethanol was passed through the reactor, and the residence time was fixed at $4 \mathrm{~h}$ (Ogo et al., 2011; Ho et al., 2016). Product yields were estimated by solving differential mass balances of the kinetic model proposed by Tsuchida et al. (2006). The reactor outlet stream was cooled to $30^{\circ} \mathrm{C}$ to separate the gaseous products from liquids. This mixture was fed to a three-tower distillation train, a decanter, and molecular sieves to obtain butanol at $99.5 \% \mathrm{w} / \mathrm{w}$, a mixture of alcohols at $96 \% \mathrm{w} / \mathrm{w}$, and ethanol at $99.5 \%$ w/w (unreacted). The mixture of alcohols consisted of hexanol, octanol, 2ethyl-1-butanol, and 2-ethyl-1-hexanol. This hydrocarbon mixture can be used as a feedstock in the chemical industry or as a fuel additive. Thus, this mixture was considered as a co-product for sale (Dias et al., 2014).

\subsubsection{Cogeneration system}

In both processes (i.e., ABE fermentation and catalytic upgrading of ethanol), the solid fraction from enzymatic hydrolysis and cell-filtration stages were used to produce heat and power in a cogeneration system (Fig. 7). The cogeneration technology was the biomass integrated gasification combined cycle (BIGCC) technology (Rincón et al., 2014). The gasification process was simulated using the procedure described by García et al. (2017b). Accordingly, an air-downdraft gasifier was used in the BIGCC system. The gasification process included four stages: (i) drying $\left(100^{\circ} \mathrm{C}\right)$, (ii) pyrolysis $\left(700^{\circ} \mathrm{C}\right)$, (iii) combustion $\left(900^{\circ} \mathrm{C}\right)$, and (iv) reduction $\left(900^{\circ} \mathrm{C}\right)$. From this process, syngas (i.e., $\mathrm{CO}, \mathrm{H}_{2}, \mathrm{CH}_{4}$ ) was obtained. This gas mixture was then combusted with pressurized air at $10 \mathrm{bar}$ and an air excess of $10 \%$ to produce heat and power through a turbine and heat exchangers.

All wastewater streams were submitted to a tertiary wastewater treatment system composed of three stages: (i) filtration, (ii) activated sludge, and (iii) chemical treatment. Finally, a list of the main assumptions made during the simulation procedure are given below:

- A CCS and OPW mass flow of 1000 ton/d each was considered in all simulations.

- Raw materials composition did not vary during the project lifetime.

- ABE fermentation was simulated as a continuous process, although experimental data were obtained in batch mode.

- No-scaling-up rules were applied. Thus, the same conditions, yields, and results at an experimental level were used in the simulation.

\subsection{Economic assessment}

The software Aspen Process Economic Analyzer was used to calculate the equipment costs based on mass and energy balances. Besides, the cost of specific equipment (e.g., bioreactors, conveyors) was calculated based on the costs reported by Humbird et al. (2011).

The economic evaluation methodology proposed by Peters et al. (2003) was used. The conditions considered to perform this analysis were (i) desired rate of return $15 \%$, (ii) project lifetime $15 \mathrm{yr}$, (iii) annual interest rate $13 \%$, (iv) income tax $25 \%$, (v) annual working time $8000 \mathrm{~h}$ bearing in mind three shifts per day (24/7), (vi) length start-up period 20 weeks, (vii) working capital 5\% per period, and (viii) straight-line depreciation method with a salvage value of $10 \%$.

Table 2 presents the cost of the raw materials, utilities, and product sale prices used to perform the cash flow analysis. The production costs were estimated using the total costs in each process. Based on the calculated total cost of the processes and the reported sales price of the products, an economic allocation was performed. With that, the production cost of each of the products was calculated (Serna-Loaiza et al., 2018). Finally, the Net Present Value (NPV) and Payback Period (PBP) were used as economic metrics to estimate economic feasibility.

Assumptions related to the raw materials, utilities, and products costs are as follows:

- The costs of raw materials involved the transportation costs by trucks for $20 \mathrm{~km}$.

- The cost of HAP was considered based on the commercial catalysts used to convert ethanol to butanol.

- The price of the enzyme was estimated as an average between enzyme case 1 - enzyme case 2 - enzyme case 3 - enzyme case 6 reported by Liu et al. (2016). 


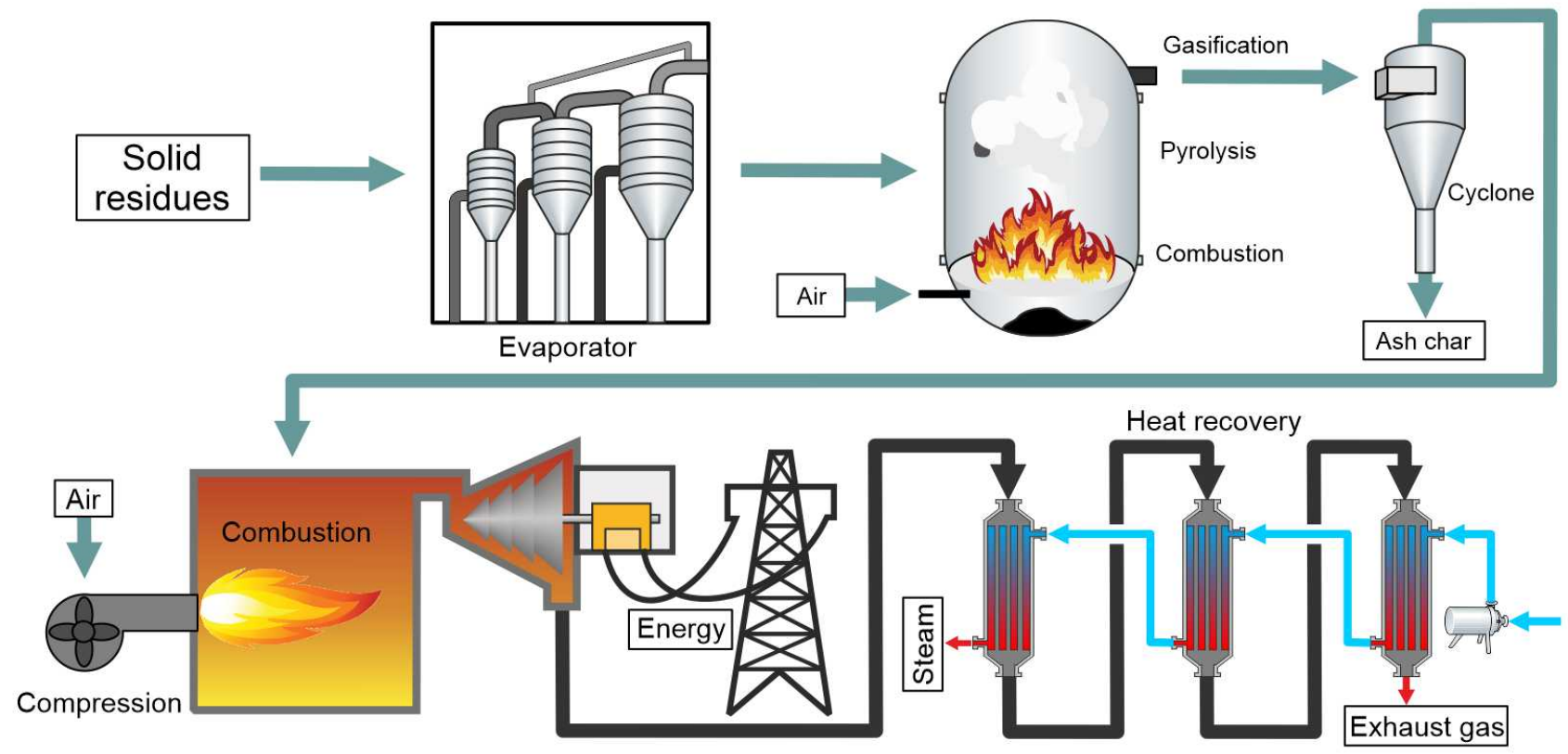

Fig. 7. Process flow diagram of biomass integrated gasification with a cogeneration system.

Table 2.

Cost of raw materials, utilities, and products used in the economic assessment.

\begin{tabular}{|c|c|c|c|}
\hline & Unit & Cost/Selling price & Reference \\
\hline \multicolumn{4}{|l|}{ Raw material } \\
\hline Coffee cut stems & USD/ton & 24 & Aristizábal-Marulanda et al. (2020) \\
\hline Orange peel & USD/ton & 22 & Ortiz-Sanchez et al. (2020) \\
\hline Water & $\mathrm{USD} / \mathrm{m}^{3}$ & 0.9 & Average value: Colombian context \\
\hline Sulfuric acid & USD/ton & 94 & García et al. (2017a) \\
\hline Enzyme 1 - Cellulase & USD/ton & 4700 & Liu et al. (2016) \\
\hline Enzyme 2 - Pectinase + Cellulase & USD/ton & 7000 & Guerrand (2018) \\
\hline Catalyst - Hydroxyapatite & $\mathrm{USD} / \mathrm{kg}$ & 75 & Nezam et al. (2019) \\
\hline \multicolumn{4}{|l|}{ Utilities } \\
\hline Cooling water & $\mathrm{USD} / \mathrm{m}^{3}$ & 0.042 & \multirow{2}{*}{$\begin{array}{l}\text { García-Velásquez and Cardona (2019); } \\
\text { Ulrich and Vasudevan (2006) }\end{array}$} \\
\hline Process water & $\mathrm{USD} / \mathrm{m}^{3}$ & 0.326 & \\
\hline Electricity & $\mathrm{USD} / \mathrm{kWh}$ & 0.1 & Average value: Colombian context \\
\hline Low-pressure steam ${ }^{\text {a }}$ & USD/ton & 7.92 & \multirow{3}{*}{ Moncada et al. (2014) } \\
\hline Medium pressure steam $^{\mathrm{a}}$ & USD/ton & 8.56 & \\
\hline High-pressure steam ${ }^{\text {a }}$ & USD/ton & 10.32 & \\
\hline \multicolumn{4}{|l|}{ Personal } \\
\hline Operator labor & $\mathrm{USD} / \mathrm{h}$ & 2.56 & \multirow{2}{*}{ Aristizábal-Marulanda et al. (2015) } \\
\hline Supervisor labor & $\mathrm{USD} / \mathrm{h}$ & 5.12 & \\
\hline \multicolumn{4}{|l|}{ Products ABE fermentation } \\
\hline Butanol & $\mathrm{USD} / \mathrm{kg}$ & 1.37 & Mariano et al. (2013) \\
\hline Acetone & $\mathrm{USD} / \mathrm{kg}$ & 1.45 & ICIS (2016) \\
\hline Ethanol & $\mathrm{USD} / \mathrm{kg}$ & $0.45^{\mathrm{b}}$ & García-Velásquez and Cardona (2019) \\
\hline \multicolumn{4}{|l|}{ Products catalytic conversion } \\
\hline Butanol & $\mathrm{USD} / \mathrm{kg}$ & 1.37 & Mariano et al. (2013) \\
\hline Ethanol & $\mathrm{USD} / \mathrm{kg}$ & 0.80 & García-Velásquez and Cardona (2019) \\
\hline Mix of alcohols & $\mathrm{USD} / \mathrm{kg}$ & 1.13 & Dias et al. (2014) \\
\hline
\end{tabular}

${ }^{\text {a }}$ Prices were updated to 2018 using the Chemical Engineering Plant Cost Index (CEPCI)

${ }^{\mathrm{b}}$ Ethanol $70 \%(\mathrm{v} / \mathrm{v})$ 


\section{- Sensitivity analysis}

The effect of plant capacity was assessed for both production technologies to determine the minimum processing scales for economic feasibility (MPSEF). The processing scale affects economic performance since higher scales could lead to decreased PBP (Serna-Loaiza et al., 2018). The impact of the processing scale on the production costs and NPV were assessed by applying the six-tenths-factor rule (Peters et al., 2003). This approach agrees with the economy of scale concept (i.e., the plant decreases operating expenses while increasing the production scale) (Bruins and Sanders, 2012). For the analysis, the hydrolysate production cost from CCS and OPW was calculated at different scales. The average flow, inversion, and annualized costs were then used to determine the total costs of the butanol production processes. On the other hand, the effect of the butanol selling price on the NPV was assessed to find the minimum selling price (MSP) to make the process feasible through a sensitivity analysis.

\subsection{Environmental assessment}

The waste reduction (WAR) algorithm GUI® software was used to estimate the environmental impact of the processes. This software calculates the potential environmental impact (PEI) based on the overall mass balance of the process and energy consumption (Young et al., 2000). The WAR algorithm developed by the National Risk Management Research Laboratory of the U.S. Environmental Protection Agency, was used. The WAR software performs the PEI impact considering global atmospheric and toxicological categories (Moncada et al., 2016). The environmental evaluation was based on the calculation of two different groups of impact categories. The global atmospheric category involves the calculation of the global warming potential (GWP), ozone depletion potential (ODP), acidification potential (AP), and photochemical oxidation potential (PCOP) as impact categories. The toxicological category involves human (i.e., human toxicity potential by ingestion (HTPI), human toxicity potential by inhalation or exposure (HTPE)) and ecological (i.e., aquatic toxicity potential (ATP), and terrestrial toxicity potential (TTP)) impact categories (Fu et al., 2000).

\section{Results and Discussion}

\subsection{Selection of the kinetic system}

\subsubsection{Bibliographic review}

The bibliographic review was carried out to find available information related to the catalytic ethanol upgrading to butanol. A review of process conditions, catalyst type, conversions, and yields associated with the catalytic ethanol conversion is presented in Table 3. Several possibilities to upgrade ethanol applying heterogeneous catalysts are presented. Molar conversions vary from $7 \%$ to $50 \%$ and butanol selectivity from $50 \%$ to $90 \%$. Operating temperatures vary between $200-350^{\circ} \mathrm{C}$. Reactions with metal catalysts usually operate at high pressures ( 70 bar), while HAP-based systems operate at atmospheric temperatures. Additionally, the catalytic conversion of ethanol is characterized by producing a considerable amount of co-products of high and low molecular weight. High temperatures favor the production of high molecular weight hydrocarbons, reducing the selectivity towards butanol. Regarding kinetic modeling, this process has not been studied in-depth since the kinetic models reported in the existing literature are simple curves without parameters estimation. Thus, most studies only report conversions, yields, and selectivity. Reaction mechanisms are well discussed, but possible kinetic routes are not calculated or proposed. Moreover, the accuracy of the proposed models is not analyzed in detail in many cases. In this context, the study of Tsuchida et al. (2006) based on HAP was considered an excellent and complete work and was chosen to simulate the catalytic conversion of ethanol.

\subsubsection{Kinetic system based on hydroxyapatite}

HAP has acid and base sites in a single-crystal lattice (Tsuchida et al., 2006). This mineral has a calcium-phosphorus molar ratio $(\mathrm{Ca} / \mathrm{P}$ ratio $)$ of 1.67 but in nonstoichiometric forms. The $\mathrm{Ca} / \mathrm{P}$ ratio can range from 1.5 to 1.7 with the loss of calcium ions. Tsuchida et al. (2006) used nonstoichiometric HAP $(\mathrm{Ca} / \mathrm{P}$ of 1.64) to catalyze ethanol conversion to n-butanol selectively. The process was done at different temperatures (i.e., $300-450^{\circ} \mathrm{C}$ ) and atmospheric pressure The authors proposed a series of reaction steps to elucidate the ethanol conversion mechanism based on the experimental conditions. They implied that those reaction steps were in agreement with the Guerbet reactions. Nevertheless, only reactions between normal alcohols (n-alcohols) were considered. The reactions used in this study are listed in Appendix 1 (Supplementary Data). The products reportedly obtained by Tsuchida et al. (2006) are (i) butanol (ButOH), (ii) hexanol (HexOH), (iii) 2-ethyl-1butanol (EtButOH), (iv) octanol (OctOH), (v) 2-ethyl-1-hexanol (EtHexOH), (vi) ethylene (Ethy), (vii) butene (Bute), (viii) hexene (Hexe), (ix) octene (Octe), (x) acetaldehyde (Acetal), (xi) 1,3-butadiene (Butadi), and (xii) aromatics. The kinetic model used to simulate the catalytic ethanol upgrading proposed by Tsuchida et al. (2006) is presented in Appendix 2 (Supplementary Data).

The differential equations system (Appendix 2) was solved considering a temperature of $350^{\circ} \mathrm{C}$ since high butanol yields were obtained at this temperature (i.e., low temperatures-low conversion, high temperatures-low selectivity) (Tsuchida et al., 2006). The results obtained are depicted in Figure 8. An ethanol molar conversion of $34 \%$ was reached at a contact time of $2 \mathrm{~s}$ (among the carbon components). Butanol obtained the highes yield, followed by hexanol, 2-ethyl-1-butanol, 2-ethyl-1-hexanol, and octanol. Besides, a selectivity of $66 \%$ was recorded in the case of butanol. The remaining percentage was distributed among the other reaction products. The kinetic modeling results, as expected, were similar to those reported by Tsuchida et al. (2006). This process was done to obtain the components` profiles to understand the process, elucidate the bestoperating conditions, reaction possibilities, and contribute to future analysis of the catalytic ethanol conversion. A residence time of $3.8 \mathrm{~h}$ was selected based on the packed-bed reactor profiles to obtain the highest butanol production. The yields obtained in the kinetic system modeling were used as input data to simulate the catalytic ethanol conversion.

\subsection{Process simulation}

The simulation results of the two technologies are presented in Table 4. For conventional ABE fermentation, Jafari et al. (2016) report a yield of 0.078 tons of butanol per ton of sweet sorghum bagasse. This value agrees with those obtained in the ABE fermentation process. In the case of catalytic conversion, there are no reports of yields from lignocellulosic residues. Besides, butanol separation was more efficient in the catalytic ethanol upgrading process.

Regarding butanol production, the catalytic process presented the lowest yield and flow of butanol. This low yield is attributed to the low conversion of ethanol (approx. 20\% molar basis). Besides, butanol production via catalytic upgrading was linked to the limitations of ethanol fermentation. From the energy requirements perspective, the produced electricity was enough to supply all the energy demand in both processes (Table 4). Indeed, the electricity surplus (negative values) was considered as an additional product for sale. $30 \%$ and $12 \%$ of the total thermal energy demand were supplied in the ABE fermentation and catalytic upgrading processes, respectively. The cogeneration system recovered the heat through steam production using hot gases from the power generation stage. In the catalytic process, the temperature required in the catalytic reactor was reached using these hot gases. Thus, a smaller amount of steam was produced in this process. The normalized heating energy requirements, considering cogeneration, were: $3.601 \mathrm{GJ} /$ ton and $5.630 \mathrm{GJ} /$ ton for the $\mathrm{ABE}$ fermentation and catalytic ethanol upgrading processes, respectively.

The thermal and electric power demands in both processes were estimated considering in both cases heat integration. Thus, in the energy requirement presented in Table 4, the implementation of a heat exchanger network (HEN) has been considered. The ABE fermentation process requires $57.9 \mathrm{GJ} /$ ton of butanol produced to supply heating requirements. In the same way, this process produces an electric energy flow of 2.07 $\mathrm{GJ} / \mathrm{ton}$ of butanol. On the other hand, the thermal demand of the catalytic ethanol upgrading is two folds (i.e., $116.57 \mathrm{GJ} / \mathrm{ton}$ of butanol) that of the ABE fermentation process. This high thermal energy consumption can be attributed to the energy requirements of the ethanol production process. The catalytic ethanol upgrading process produces less electricity than the $\mathrm{ABE}$ fermentation process (i.e., $1.78 \mathrm{GJ} /$ ton of butanol). Thus, butanol production via fermentation is the best alternative to produce butanol from 
Table 3.

General review of catalytic conversion of ethanol to butanol using different catalysts

\begin{tabular}{|c|c|c|c|c|c|c|c|}
\hline Catalyst & Catalyst load & $\begin{array}{l}\text { Condition and type of } \\
\text { reactor }\end{array}$ & $\begin{array}{c}\text { Molar } \\
\text { conversion } \\
\text { of ethanol } \\
(\%)^{\mathrm{a}}\end{array}$ & $\begin{array}{l}\text { Selectivity } \\
\text { for butanol } \\
\quad(\%)^{\mathrm{a}}\end{array}$ & Co-products & Profiles or kinetics & Reference \\
\hline Hydroxyapatite (HAP) & $\begin{array}{l}-20 \%(\text { vol ethanol/He }) \\
\text { - Gas space velocity: } \\
10000 \mathrm{~L} / \mathrm{h} \\
-0.6 \mathrm{~mL} \text { of catalyst }\end{array}$ & $\begin{array}{l}300^{\circ} \mathrm{C}, 1.78 \mathrm{~s}, 1 \text { bar, fixed- } \\
\text { bed tubular reactor }\end{array}$ & 27 & 68.8 & $\begin{array}{l}\text { Ethylene, } \\
\text { propylene, } \\
\text { acetaldehyde, } \\
\text { 2-ethyl-1butanol, } \\
n \text {-hexanol, } \\
n \text {-octanol, } \\
n \text {-decanol, } \\
\text { olefins, aromatics }\end{array}$ & Kinetic expression & $\begin{array}{l}\text { Tsuchida et al. } \\
\text { (2006) }\end{array}$ \\
\hline $\begin{array}{l}\mathrm{Cu}-\mathrm{Mg}-\mathrm{Al} \\
\mathrm{Cu}_{5} \mathrm{MgAl}_{(1)} \mathrm{O}\end{array}$ & $0.01 \mathrm{~g}$ catalyst $/ \mathrm{mL}$ ethanol & $\begin{array}{l}200^{\circ} \mathrm{C}, 70 \mathrm{bar}, 25 \mathrm{~h}, \text { Steel } \\
\text { autoclave equipped with an } \\
\text { agitator }\end{array}$ & 7.3 & 50.5 & $\begin{array}{l}\text { Ethyl acetate, } \\
\text { diethyl ether, } \\
\text { acetaldehyde, } \\
\text { butyraldehyde, } \\
\text { 1,1-diethoxyethane, } \\
\text { 1,1-diethoxybutane }\end{array}$ & - & $\begin{array}{l}\text { Marcu et al. } \\
(2009)\end{array}$ \\
\hline $\begin{array}{l}\mathrm{Mg}-\mathrm{Al} \\
3: 1\end{array}$ & $\begin{array}{l}24.7 \mathrm{~h} \mathrm{~g} \text { catalyst } / \mathrm{mol} \\
\text { ethanol }\end{array}$ & $\begin{array}{l}5.5 \% \text { (vol. ethanol/He), } \\
350^{\circ} \mathrm{C}, 10 \mathrm{~h} \\
\text { U-shaped quartz reactor with } \\
\text { catalyst bed }\end{array}$ & 25 & 16 & $\begin{array}{l}\text { Ethylene, } \\
\text { acetaldehyde, } \\
\text { 2-buten-1-ol, } \\
\text { butyraldehyde }\end{array}$ & - & $\begin{array}{l}\text { León et al. } \\
\text { (2011) }\end{array}$ \\
\hline $\begin{array}{l}\text { Strontium phosphate } \\
\text { hydroxyapatite }\end{array}$ & $\begin{array}{l}130 \mathrm{~h} \mathrm{~g} \text { catalyst } / \mathrm{mol} \\
\text { ethanol }\end{array}$ & $\begin{array}{l}16.1 \%(\mathrm{~mol} \text { ethanol/Ar), } \\
300^{\circ} \mathrm{C}, 3 \mathrm{~h}, 1 \mathrm{bar} \\
\text { fixed bed reactor }\end{array}$ & 7.6 & 81.2 & $\begin{array}{l}\text { Ethylene, } \\
\text { acetaldehyde, } \\
\text { 2-buten-1-ol, } \\
\text { 1-hexanol, olefins }\end{array}$ & - & Ogo et al. (2011) \\
\hline $\begin{array}{l}\mathrm{Ni} / \mathrm{Al}_{2} \mathrm{O}_{3} \\
(\mathrm{HTC}-500)^{\mathrm{b}}\end{array}$ & $\begin{array}{l}0.033 \mathrm{~g} \text { catalyst } / \mathrm{mL} \\
\text { ethanol }\end{array}$ & $\begin{array}{l}250^{\circ} \mathrm{C}, 70 \text { bar, } 1500 \mathrm{rpm} \\
72 \mathrm{~h} \text {, autoclave equipped } \\
\text { with a mechanical Rushton } \\
\text { turbine }\end{array}$ & 25 & 80 & $\begin{array}{l}\text { Ethyl acetate, } \\
\text { 1-hexanol, } \\
\text { diethyl ether, } \\
\text { butyraldehyde, } \\
\text { acetaldehyde }\end{array}$ & $\begin{array}{l}\text { Concentration } \\
\text { profiles }\end{array}$ & $\begin{array}{l}\text { Riittonen et al. } \\
(2012)^{\mathrm{c}}\end{array}$ \\
\hline $\begin{array}{l}\mathrm{Mg}-\mathrm{Al} \\
3: 1\end{array}$ & $\begin{array}{l}12 \%\left(\mathrm{vol} \text { ethanol } / \mathrm{N}_{2}\right) \text { at } 40 \\
\mathrm{~mL} / \mathrm{min} \text { on a catalyst mass } \\
\text { of } 300 \mathrm{mg}\end{array}$ & $350^{\circ} \mathrm{C}, 8 \mathrm{~h}$, fixed bed reactor & 30 & 38 & $\begin{array}{l}\text { Ethylene, } \\
\text { butyraldehyde, } \\
\text { acetaldehyde, } \\
\text { C4 compounds }\end{array}$ & - & $\begin{array}{l}\text { Carvalho et al. } \\
\text { (2012) }\end{array}$ \\
\hline $\begin{array}{l}\left.\mathrm{RuCl}\left(\eta^{6}-\rho \text { - cymene }\right)\right] \\
\text { with ligand }\end{array}$ & $\begin{array}{l}0.012 \mathrm{~g} \text { catalyst } / \mathrm{mL} \\
\text { ethanol }\end{array}$ & $\begin{array}{l}150^{\circ} \mathrm{C}, 4 \mathrm{~h} \text {, steel autoclave, } \\
\text { magnetic stirring }\end{array}$ & 22 & 94 & $\begin{array}{l}\text { 2-Ethylbutanol, } \\
\text { n-hexanol }\end{array}$ & - & $\begin{array}{l}\text { Dowson et al. } \\
(2013)\end{array}$ \\
\hline $\mathrm{Pd}_{5} \mathrm{MgAlO}$ & $0.01 \mathrm{~g}$ catalyst $/ \mathrm{mL}$ ethanol & $\begin{array}{l}260^{\circ} \mathrm{C}, 5 \mathrm{~h}, 70 \mathrm{bar} \text {, steel } \\
\text { autoclave equipped with an } \\
\text { agitator }\end{array}$ & 17 & 81 & $\begin{array}{l}\text { acetaldehyde, } \\
\text { 1,1-diethoxyethane, } \\
\text { butyraldehyde, } \\
\text { ethyl acetate, } \\
\text { diethyl ether }\end{array}$ & - & $\begin{array}{l}\text { Marcu et al. } \\
(2013)\end{array}$ \\
\hline Hydroxyapatite & $\begin{array}{l}\text { - } 0.3 \mathrm{~g} \text { of catalyst } \\
\text { - Partial pressure ethanol: } \\
5.7 \mathrm{kPa}\end{array}$ & $\begin{array}{l}330^{\circ} \mathrm{C}, 1 \mathrm{bar} \\
\text { packed-bed reactor }\end{array}$ & 17.1 & 63.2 & $\begin{array}{l}\text { Ethylene, } \\
\text { acetaldehyde, } \\
\text { butadiene, } \\
\text { crotonaldehyde, } \\
\text { butanal, } \\
\text { C6+alchols }\end{array}$ & $\begin{array}{l}\text { Kinetic expression } \\
\text { only for two } \\
\text { products }\end{array}$ & Ho et al. (2016) \\
\hline $\begin{array}{l}\text { Ruthenium complex with } \\
\text { sodium ethoxide co- } \\
\text { catalyst }\end{array}$ & $\begin{array}{l}\text { - } 142 \mathrm{mg} \text { catalyst } \\
-17.2 \mathrm{mmol} \mathrm{NaOEt} \\
-0.5 \mathrm{~mL} \text { ethanol }\end{array}$ & $150^{\circ} \mathrm{C}, 4 \mathrm{~h}$, Schlenk bomb & 46 & 43 & $\mathrm{C}_{6}-\mathrm{C}_{10}$ alcohols & - & $\begin{array}{l}\text { Mazzoni et al. } \\
\text { (2019) }\end{array}$ \\
\hline
\end{tabular}

${ }^{a}$ Highest values reported. ${ }^{b}$ Commercial catalyst. ${ }^{c}$ In this study, 13 heterogeneous catalysts were screened and the most promising was $\mathrm{Ni} / \mathrm{Al}_{2} \mathrm{O}_{3}$.

an energy perspective. Nevertheless, the energy requirements of the catalytic upgrading process could be reduced if the in-situ production of ethanol were not considered. Finally, the butanol produced can supply $50 \%$ (i.e., $75 \mathrm{GJ} / \mathrm{h}$ ) and $25 \%(58.80 \mathrm{GJ} / \mathrm{h})$ of the thermal requirements of the $\mathrm{ABE}$ fermentation and catalytic ethanol upgrading processes, respectively. This estimation was done assuming a butanol heating value of $29.2 \mathrm{GJ} / \mathrm{m}^{3}$. From these results, the $\mathrm{ABE}$ fermentation process is profiled as a more efficient process than catalytic ethanol upgrading since more energy is conserved in the final product.

\subsection{Economic assessment}

The economic analysis was based on different parameters, such as annualized cost (e.g., operating expenditures (OPEX), capital expenditures
(CAPEX), NPV, and revenues). Table 5 tabulates the results of the economic assessment of the two processing technologies. The catalytic conversion process presented a higher CAPEX and production costs (i.e., utilities and depreciation) because more process units and utility usage were required. In terms of NPV, both technologies presented a negative value. This behavior implies more expenses than revenues (i.e., gains). Thus, $\mathrm{ABE}$ fermentation and catalytic ethanol upgrading are not unfeasible processes at the studied processing scale (i.e., 1000 ton/d). The ABE fermentation process presented a lower negative value, which can be attributed to the lower annualized operation costs of this process. Overall, based on the findings presented, the $\mathrm{ABE}$ fermentation process would be a better alternative to produce butanol from biomass from both technical and economic perspectives. The catalytic conversion did not show better 


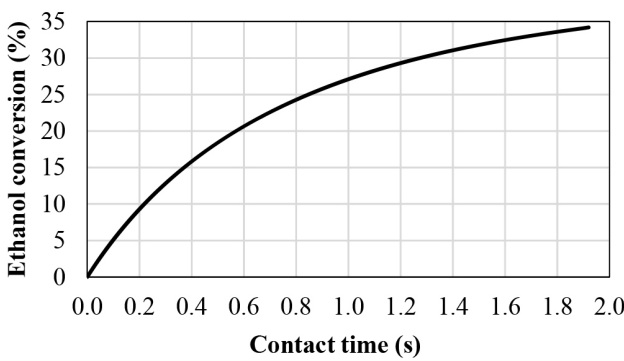

Ethanol

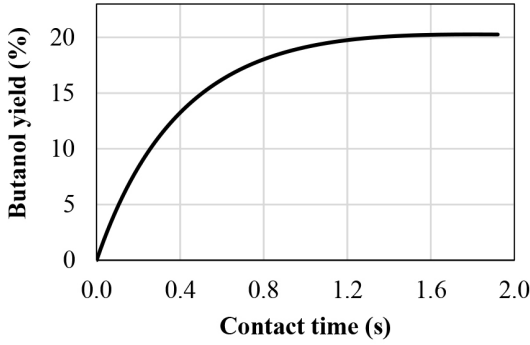

-Butanol

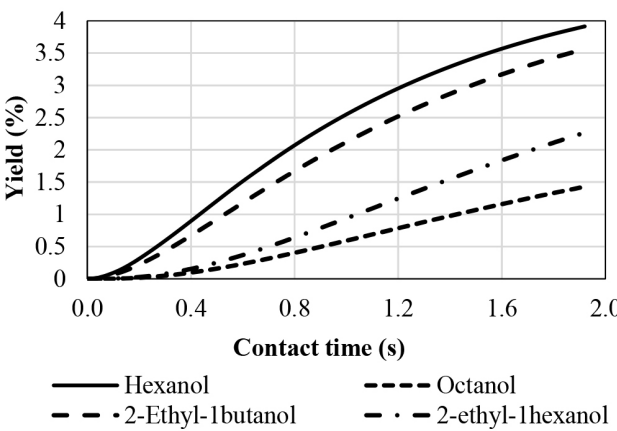

Fig. 8. Ethanol conversion and product yields over time at $350^{\circ} \mathrm{C}$.

Table 4

Obtained amounts of products, yields, and energy requirements for conventional ABE fermentation and catalytic upgrading of ethanol processes.

\begin{tabular}{|c|c|c|}
\hline & Conventional ABE fermentation & Catalytic ethanol upgrading \\
\hline \multicolumn{3}{|l|}{ Product } \\
\hline Butanol flow [ton/h] & 2.592 & 2.014 \\
\hline Yield [ton/ton RM $\mathrm{RM}^{\mathrm{a}}$ ] & 0.062 & 0.048 \\
\hline Butanol recovery [\% of total produced] & 89 & 94 \\
\hline \multicolumn{3}{|l|}{ Co-products } \\
\hline Acetone flow [ton/h] & 1.056 & - \\
\hline Acetone yield [ton/ton RM] & 0.025 & - \\
\hline Acetone recovery [ $\%$ of total produced] & 99 & - \\
\hline Ethanol flow [ton/h] & $0.291^{\mathrm{b}}$ & 1.341 \\
\hline Yield [ton/ton RM] & 0.007 & 0.032 \\
\hline Ethanol recovery [ $\%$ of total produced] & 69 & $82^{c}$ \\
\hline Mixed alcohols flow [ton/h] & - & 1.820 \\
\hline Yield [ton/ton RM] & - & 0.044 \\
\hline Mixed alcohols recovery [\% of total produced] & - & 99 \\
\hline \multicolumn{3}{|l|}{ Energy requirements $(\mathbf{G J} / \mathbf{h})$} \\
\hline Cooling & 135.180 & 203.089 \\
\hline Heating (required) & 213.370 & 268.307 \\
\hline Heating (produced) ${ }^{\mathrm{d}}$ & 63.224 & 33.537 \\
\hline Heating (net) & 150.146 & 234.770 \\
\hline Electricity (required) & 17.024 & 18.810 \\
\hline Electricity (produced) & 22.406 & 22.387 \\
\hline Electricity (net) & -5.382 & -3.591 \\
\hline
\end{tabular}

${ }^{\mathrm{a}} \mathrm{RM}$ : raw material

${ }^{\mathrm{b}}$ Ethanol $70 \%(\mathrm{v} / \mathrm{v})$

${ }^{\mathrm{c}}$ Calculated based on unreacted ethanol

${ }^{\mathrm{d}}$ Produced by the cogeneration system as medium pressure steam (MPS)

economic performance because bioethanol production was considered.

The production costs were estimated using an economic allocation since all simulations involve more than one product. Table 6 presents the economic allocation factor and the production costs for the investigated butanol production processes. Butanol was the compound that had the most significant economic contribution in both processes and, therefore, the largest allocating factor. All the estimated production costs were higher than the selling prices. Thus, the profit margin of both processes was negative, implying a negative NPV (Table 5)

Qureshi et al. (2013) reported a production cost of 1.037 USD $/ \mathrm{kg}$ of butanol from wheat straw biomass. The plant was simulated considering a processing scale of 2200 ton/d. The process was composed of (i) dilute acid pretreatment, (ii) enzymatic saccharification, (iii) batch fermentation, (iv) pervaporation product recovery, and (v) distillation separation (Qureshi et al., 2013). Tao et al. (2014) obtained a production cost of $1.088 \mathrm{USD} / \mathrm{kg}$ of butanol considering a corn stover mass flow of 2000 ton/d. Besides, Jang and Choi (2018) evaluated butanol production from lignocellulosic biomass by acid pretreatment, hydrolysis, continuous fermentation, and nonconventional separation. The authors reported a production cost of 1.427 USD/kg using an almost similar processing scale to the studies mentioned above. Thus, butanol production costs via ABE fermentation range between 1.0 and 1.4 USD per kg butanol. However, the comparison of the butanol 
Table 5.

Annualized production costs, investment, revenues, and NPV for the investigated butanol production technologies for a processing scale of 1000 ton/d (41.7 ton/h).

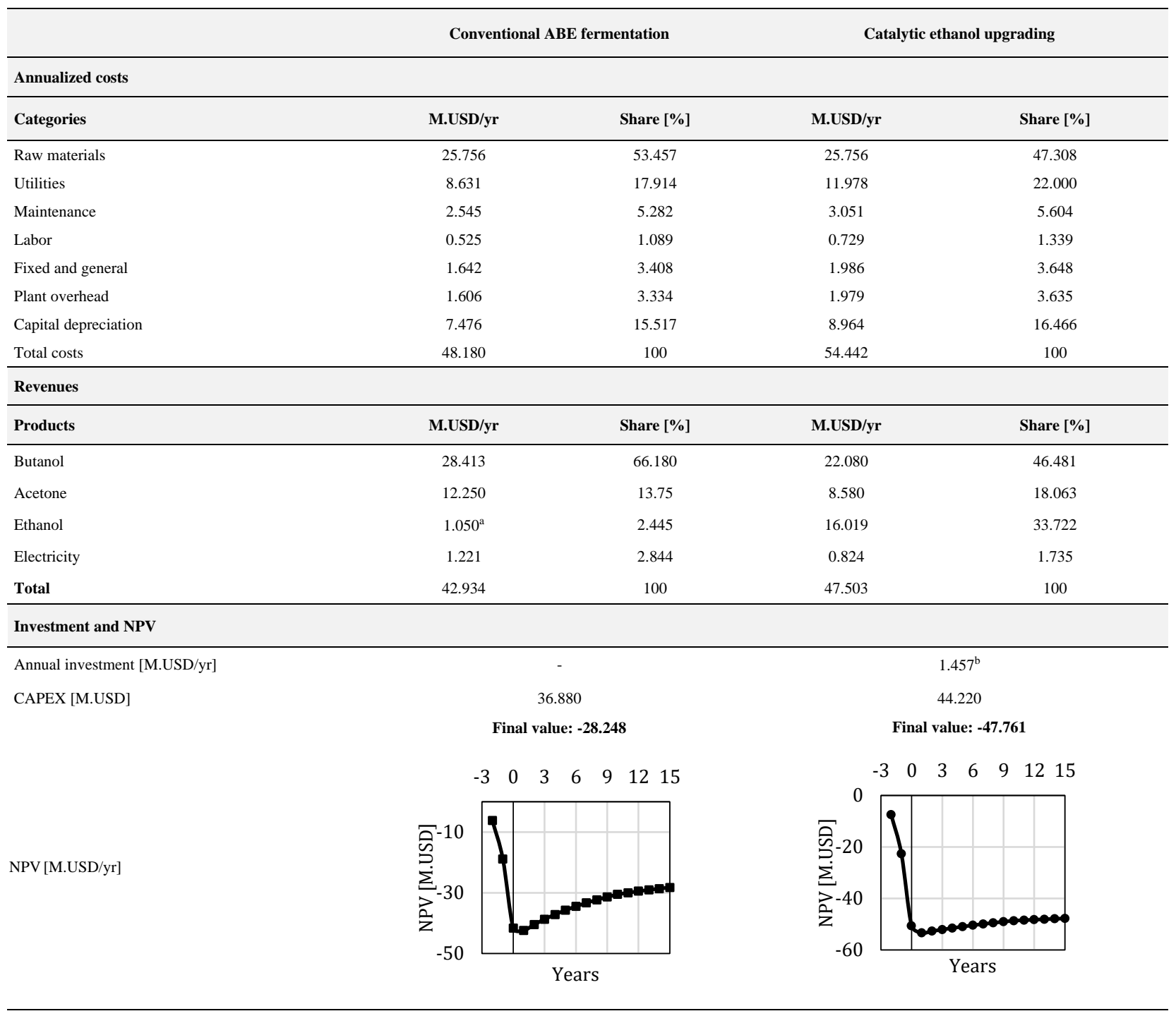

${ }^{\mathrm{a}}$ Ethanol 70\% (v/v)

${ }^{\mathrm{b}}$ Catalyst renewal

Table 6.

Allocation factor and production costs for the conventional ABE fermentation and catalytic upgrading of ethanol processes.

\begin{tabular}{lcccc}
\hline \multirow{2}{*}{ Product } & \multicolumn{2}{c}{ Conventional ABE fermentation } & \multicolumn{2}{c}{ Catalytic ethanol upgrading $^{\text {Selling price }}$} \\
\cline { 2 - 5 } & Production cost [USD/kg] & Allocation factor & Production cost [USD/kg] & Allocation factor \\
\hline Butanol & 1.537 & 0.662 & 1.570 & 0.465 \\
Acetone & 1.627 & 0.285 & - & - \\
Ethanol & 0.505 & 0.025 & 0.917 & 0.181 \\
Mixed alcohols & - & - & 1.261 & 0.337 \\
Electricity & 0.112 & 0.028 & 0.115 & $0.45^{\mathrm{b}}-0.8^{\mathrm{c}}$ \\
\hline
\end{tabular}

a See Table 2.

b $70 \%$ wt.

${ }^{\mathrm{c}} 99.6 \% \mathrm{wt}$. 
production costs is problematic since this cost depends on many factors such as the type and cost of the feedstock, product yields, process conditions, and processing scale; some approximations can be made though.

In the case of the catalytic ethanol upgrading, no economic analyses have been done considering a similar process configuration. Nezam et al. (2019) conducted a techno-economic analysis of the catalytic conversion stage, considering an ethanol cost of $0.53 \mathrm{USD} / \mathrm{kg}$. The study reported an n-butanol selling price of $1.55 \mathrm{USD} / \mathrm{kg}$, bearing in mind a $25 \%$ return on investment. The required ethanol flow was $51 \mathrm{ton} / \mathrm{h}$.

A processing scale of 8160 ton/d of lignocellulosic biomass would be required if a $20 \%$ mass yield were considered. This processing scale is too large compared to the ethanol facilities globally. For instance, Du Pony (Iowa, USA) processes 38 ton/h of corn stover to produce $12 \mathrm{ton} / \mathrm{h}$ of ethanol, and Abengoa Bioenergy Biomass (Kansas, USA) processes 44 ton/h of lignocellulosic residues to produce $10 \mathrm{ton} / \mathrm{h}$ of ethanol. Therefore, the estimated processing scale required to produce butanol from lignocellulosic biomass is not realistic.

According to the economic analysis conducted herein, none of the butanol production processes presented economic feasibility at the proposed processing scale of 1000 ton/d (Table 5). Therefore, a sensitivity analysis was carried out to determine processing scales with positive profit margins.

Figure 9 shows the final NPV values calculated with different processing scales for the butanol production technologies. In both cases, an increase of the processing scale favored the economic performance (i.e., increased the NPV and PBP). The MPSEF was 66 ton/h $(1584$ ton/d) and 80 ton/h $(1920$ ton/d) for the ABE fermentation and catalytic ethanol upgrading processes, respectively. Values above these scales generated positive profit margins and positive NPV. $\mathrm{ABE}$ fermentation was the process with better economic performance. For catalytic ethanol upgrading, the break-even point was achieved by operating at 1.9 times larger plant capacity than the base case (41.7 ton/h or 1000 ton/d).

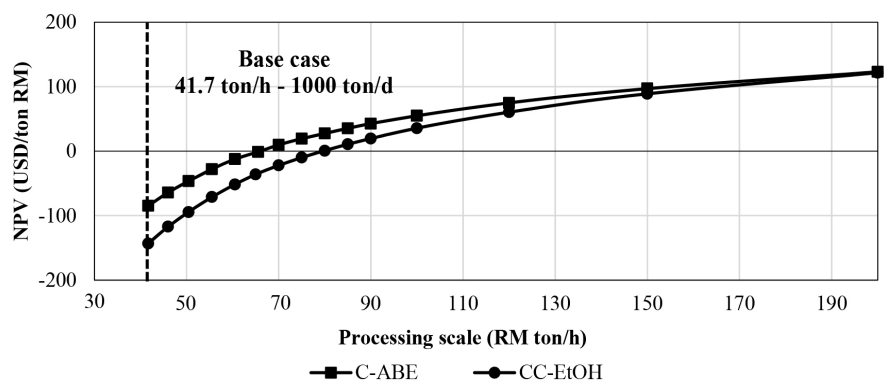

Fig. 9. Effect of plant capacity on NPV of each processing technology (RM: raw material CCS or OPW; C-ABE: conventional ABE fermentation; CC-EtOH: Catalytic conversion of bioethanol).

Finally, the economic allocation analysis elucidated butanol as the product with the highest contribution to the economic feasibility of both processes. The economic results tabulated in Table 5 were estimated considering a butanol selling price of $1.37 \mathrm{USD} / \mathrm{kg}$. Nevertheless, a sensitivity analysis was done to find the MSP of butanol to make both processes feasible. From this analysis, the MSP of butanol was estimated at $1.56 \mathrm{USD} / \mathrm{kg}$ and $1.80 \mathrm{USD} / \mathrm{kg}$ for conventional $\mathrm{ABE}$ fermentation and catalytic ethanol upgrading, respectively. These values are similar to those reported by some other researchers who produced butanol by fermentation (Baral and Shah, 2016). However, a competitive price must be less than 1.4 USD/kg (Naleli, 2016; Dalle Ave and Adams, 2018). Therefore, the economic behavior of the processes at different processing scales must be determined since an increase in the scale would decrease expenses and generate a positive NPV.

Figure 10 shows the MSP of butanol calculated at different plant capacities. The process that presented lower MSP of butanol at lower processing scales was conventional ABE fermentation. The range of MSP and scale for economic feasibility were 1.345-1.030 USD/kg and 70-200 RM ton/h, respectively. For the catalytic ethanol upgrading, the range of MSP and scale for economic feasibility were $1.334-0.934 \mathrm{USD} / \mathrm{kg}$ and $85-200 \mathrm{RM}$ ton/h, respectively.

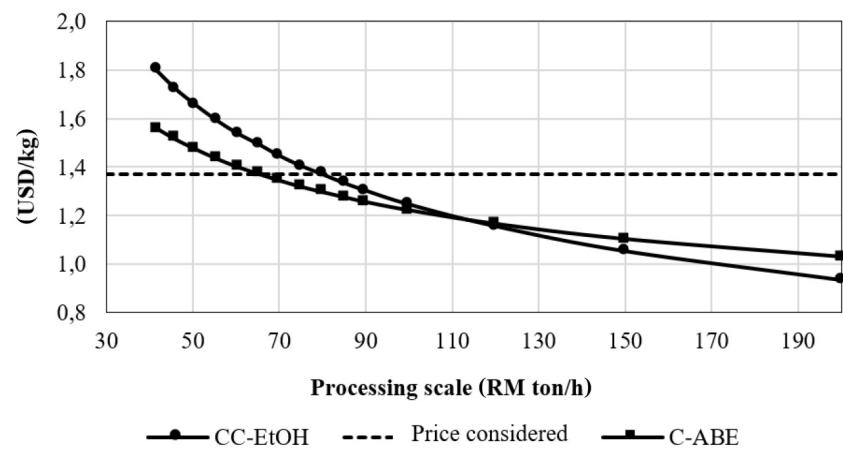

Fig. 10. Effect of plant capacity on the minimum selling price of butanol for the investigated processing technologies (RM: raw material CCS or OPW; C-ABE: conventional ABE fermentation; CC-EtOH: Catalytic conversion of bioethanol).

\subsection{Environmental assessment}

\subsubsection{Sugars production}

The environmental impact assessment results are based on the pollution potential of the process outlet streams. In the hydrolysate production, the waste streams are the stream rich in xylose $\left(\mathrm{C}_{5}\right)$ (see Fig. 3 ) and the stream of diluted limonene (W+L) (see Fig. 4) for CCS and OP, respectively. The glucose hydrolysate and lignin streams were considered products since they were the inputs for the other processes. The results of the sugars platform production using OPW and CCS are presented in Figure 11. For CCS, the categories with the highest contribution to the total PEI were the HTPI, HTPE, and TTP, followed by the AP and the other categories with low contributions. The first three categories are related to the local toxicological impact generated on humans and terrestrial organisms. These categories are calculated as a function of the LD50 oral standard toxicity indicator (lethal dose per ingestion for $50 \%$ of a given test population) (Young et al., 2000). Sulfuric acid was the compound present in the waste stream with more significant toxicity for terrestrial organisms having an LD50 value equal to $2140 \mathrm{mg} / \mathrm{kg}(\mathrm{CSBP}, 2015)$.

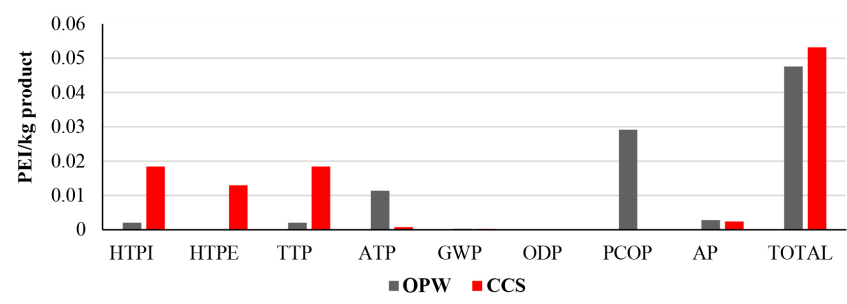

Fig. 11. Potential environmental impact (PEI) for the sugars platform production from coffe cut stems (CCS) and orange peel waste (OPW) for a processing scale of $1000 \mathrm{ton} / \mathrm{d}$.

Regarding OPW, the categories with the highest contribution to the total PEI were PCOP and ATP. This considerable impact could be attributed to the limonene content in the waste stream since the oxidation of terpenes present in this compound leads to smog generation (Falk Filipsson et al. 1998). Additionally, limonene is highly toxic to aquatic organisms. In contrast, this component (i.e., limonene) does not represent a risk to human health (Falk Filipsson et al., 1998). Finally, both processes had a similar total PEI, although the impact categories with the highest contribution differed.

\subsubsection{Butanol production routes}

The impacts of the biobutanol production routes presented here do not include the pretreatment and hydrolysis stages (discussed in the previous 
section) to focus on the waste streams of each process solely during the butanol production stage. The waste streams considered were those presented in the process flow diagrams (Figs. 5 and 6). Figure 12 shows the environmental analysis results for the two butanol production routes, considering the cogeneration system. In both processes, the PCOP category presented the highest value. Photochemical smog is the product of the reaction between volatile organic compounds (VOC) and nitrogen oxides $\left(\mathrm{NO}_{\mathrm{X}}\right)$ in the presence of UV radiations (Durkee, 2008). In both cases, the waste streams generated in the separation stages contained VOCs that could react with UV light and create this impact. Comparatively, the impact associated with conventional ABE fermentation was lower since a high proportion of butanol and ethanol was recovered. In the catalytic ethanol upgrading process, a considerable proportion of the products was also obtained. However, the PCOP values were higher due to the VOC produced (e.g., aromatics, alkenes, acetaldehyde and, 1,3 butadiene).

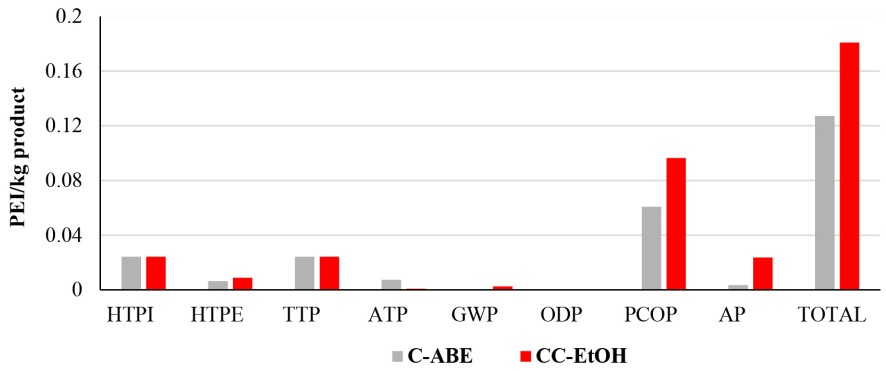

Fig. 12. Potential environmental impact (PEI) for the investigated butanol production routes (1000 ton/d) (C-ABE: ABE conventional fermentation; CC-EtOH: Catalytic conversion of bioethanol).

On the other hand, the HTPI, HTPE, and TTP impact categories presented similar values in both processes. The impacts of toxicological categories can be explained by the presence of compounds such as solvents, acids (acetic and butyric acid), aromatics, and others in the waste streams. If these streams are discharged to soil or water, contact or consumption can cause adverse health effects on terrestrial or aquatic organisms. Regarding the AP impact category, the obtained value could be attributed to the carbon dioxide released during energy production. Overall, the catalytic ethanol upgrading processes led to a higher environmental impact.

\section{Conclusions and future research needs}

Based on the literature review carried out to comprehend the state-of-the-art of catalytic ethanol upgrading to butanol, the maximum ethanol conversions and butanol yield were found to be $50 \%$ and $30 \%$, respectively. Accordingly, a HAP-based system was chosen as the best catalyst due to the moderate operating conditions compared to other catalysts. This catalyst requires less residence time to achieve an acceptable ethanol conversion and yields a considerable proportion of $\mathrm{C}_{6}$ and $\mathrm{C}_{8}$ alcohols (potentially value-added products).

Moreover, comprehensive conceptual designs of the two butanol production technologies, i.e., conventional $\mathrm{ABE}$ fermentation and catalytic ethanol upgrading, were provided using experimental data and general information reported in the literature. From the butanol production point of view, conventional $\mathrm{ABE}$ fermentation was found a better alternative. From the economic perspective, a processing scale of $1000 \mathrm{ton} / \mathrm{d}$ (41.7 ton/h, base case) was found insufficient to reach economic feasibility since the NPV values obtained were negative and only considerably higher scales could change this result. Nevertheless, at the analyzed scale, conventional ABE fermentation presented less negative NPV, and thus, it was more advantageous economically $v s$. catalytic ethanol upgrading. Similarly, the environmental analysis revealed that the ABE fermentation path led to a lower impact. Overall, it could be concluded that the catalytic upgrading of ethanol to butanol would not be a feasible production alternative compared to conventional $\mathrm{ABE}$ fermentation at present. The main reason for this conclusion is that ethanol production from lignocellulosic biomass is currently a costly process. Moreover, catalytic ethanol upgrading still requires the development of more robust catalysts in terms of conversion rate and selectivity. Overcoming these barriers would be the only way to ensure a better economic and environmental performance for the catalytic ethanol upgrading and should be the focus of future studies.

\section{Acknowledgments}

This work was supported by FONTAGRO (Project-ATN/RF- 16111RG - Productivity and competitiveness Andean fruit). The authors would like to express their acknowledgments to the Project entitled "Biorefinería para el tratamiento de residuos de cítricos - Biorefinery of Citrus Processing Waste (CPW)" from ERANET LAC 2017 and Ministerio de Ciencia, Tecnologia e Innovacion (MINCIENCIAS - ERANET-LAC) for financing this research. The authors would also like to express their gratitude to the project "Techno-economic and environmental evaluation of a biorefinery using the residues from the Coffee Crop" Grant No. 202010014230 and HERMES code 30928, the Sistema de Información de la Investigación de la Universidad Nacional de Colombia (HERMES) for the international mobility according to request HERMES 8402. Moreover, this paper is the result of the research work developed through the program: PROGRAMA DE INVESTIGACIÓN RECONSTRUCCIÓN DEL TEJIDO SOCIAL EN ZONAS DE POS-CONFLICTO EN COLOMBIA SIGP Code: 57579 within the research project "COMPETENCIAS EMPRESARIALES Y DE INNOVACIÓN PARA EL DESARROLLO ECONÓMICO Y LA INCLUSIÓN PRODUCTIVA DE LAS REGIONES AFECTADAS POR EL CONFLICTO COLOMBIANO" SIGP Code: 58907. Funded within the framework of Colombia Científica, Contract No FP44842-213-2018.

\section{References}

[1] Abdul Razak, M.N., Ibrahim, M.F., Yee, P.L., Hassan, M.A., AbdAziz, S., 2013. Statistical optimization of biobutanol production from oil palm decanter cake hydrolysate by Clostridium acetobutylicum ATCC 824. BioResources. 8(2), 1758-1770.

[2] Al-Shorgani, N.K.N., Shukor, H., Abdeshahian, P., Kalil, M.S., Yusoff, W.M.W., Hamid, A.A., 2016. Enhanced butanol production by optimization of medium parameters using Clostridium acetobutylicum YM1. Saudi J. Biol. Sci. 25(7), 1308-1321.

[3] Aristizábal-Marulanda, M.V., Gómez, P.A., Cardona, A.C.A., 2015. Biorefineries based on coffee cut-stems and sugarcane bagasse furan-based compounds and alkanes as interesting products. Bioresour. Technol. 196, 480-489.

[4] Aristizábal-Marulanda, V., Solarte-Toro, J.C., Cardona-Alzate, C.A., 2020. Economic and social assessment of biorefineries: the case of coffee cut-stems (CCS) in Colombia. Bioresour. Technol. Rep. 9, 100397.

[5] Baral, N.R., Shah, A., 2016. Techno-economic analysis of cellulosic butanol production from corn stover through acetone-butanol ethanol fermentation. Energy Fuels. 30(7), 5779-5790.

[6] Boluda-Aguilar, M., García-Vidal, L., del Pilar González-Castañeda, F., López-Gómez, A., 2010. Mandarin peel wastes pretreatment with steam explosion for bioethanol production. Bioresour. Technol. 101(10), 3506-3513.

[7] Boluda-Aguilar, M., López-Gómez, A., 2013. Production of bioethanol by fermentation of lemon (Citrus limon L.) peel wastes pretreated with steam explosion. Ind. Crops Prod. 41, 188-197.

[8] Bruins, M.E., Sanders, J.P.M., 2012. Small-scale processing of biomass for biorefinery. Biofuels, Bioprod. Biorefin. 6(2), 135-145.

[9] Carvalho, D.L., De Avillez, R.R., Rodrigues, M.T., Borges, L.E.P., Appel, L.G., 2012. Mg and Al mixed oxides and the synthesis of $\mathrm{n}$ butanol from ethanol. Appl. Catal., A. 415-416, 96-100.

[10] CSBP, 2015. Safety data sheet: sulfuric acid.

[11] Dalle Ave, G., Adams, T.A., 2018. Techno-economic comparison of Acetone-Butanol-Ethanol fermentation using various extractants. Energy Convers. Manage. 156, 288-300. 
[12] Dias, M.O.S., Pereira, L.G., Junqueira, T.L., Pavanello, L.G., Chagas, M.F., Cavalett, O., Maciel Filho, R., Bonomi, A., 2014. Butanol production in a sugarcane biorefinery using ethanol as feedstock. Part I: integration to a first-generation sugarcane distillery. Chem. Eng. Res. Des. 92(8), 1441-1451

[13] DOW, 2013. Product Safety Assessment DOWTM n-Butanol.

[14] Dowson, G.R.M., Haddow, M.F., Lee, J., Wingad, R.L., Wass, D.F., 2013. Catalytic conversion of ethanol into an advanced biofuel: unprecedented selectivity for n-butanol. Angew. Chem. Int. Ed. 52(34), 9005-9008

[15] Durkee, J.B., 2008. Chapter11-Cleaning with Solvents. Dev. Surf. Contam. Clean. (Second Ed). 479-577.

[16] Esteghlalian, A., Hashimoto, A.G., Fenske, J.J., Penner, M.H., 1997. Modeling and optimization of the dilute-sulfuric-acid pretreatment of corn stover, poplar, and switchgrass. Bioresour. Technol. 59(2-3), 129136.

[17] Falk Filipsson, A., Bard, J., Karlsson, S., 1998. World health organization \& international programme on chemical safety. Limonene. Geneva.

[18] Forgács, G., Pourbafrani, M., Niklasson, C., Taherzadeh, M.J., Hováth, I.S., 2012. Methane production from citrus wastes: process development and cost estimation. J. Chem. Technol. Biotechnol. 87(2), 250-255.

[19] Fu, Y., Diwekar, U.M., Young, D., Cabezas, H., 2000. Process design for the environment: a multi-objective framework under uncertainty. Clean Prod. Process. 2(2), 92-107.

[20] García-Velásquez, C.A., Cardona, C.A., 2019. Comparison of the biochemical and thermochemical routes for bioenergy production: a techno-economic (TEA), energetic and environmental assessment. Energy. 172, 232-242.

[21] García, C.A., Betancourt, R., Cardona, C.A., 2017a. Stand-alone and biorefinery pathways to produce hydrogen through gasification and dark fermentation using Pinus Patula. J. Environ. Manage. 203 part2, 695703.

[22] García, C.A., Moncada, J., Aristizábal, V., Cardona, C.A., 2017b. Techno-economic and energetic assessment of hydrogen production through gasification in the Colombian context: coffee cut-stems case. Int. J. Hydrogen Energy. 42(9), 5849-5864.

[23] Gebreyohannes, S., Neely, B.J., Gasem, K.A.M., 2014. One-parameter modified nonrandom two-liquid (NRTL) activity coefficient model. Fluid Phase Equilib. 379, 196-205.

[24] Gu, Y., Li, J., Zhang, L., Chen, J., Niu, L., Yang, Y., Yang, S., Jiang, W., 2009. Improvement of xylose utilization in Clostridium acetobutylicum via expression of the talA gene encoding transaldolase from Escherichia coli. J. Biotechnol. 143(4), 284-287.

[25] Guerrand, D., 2018. Chapter 26 - Economics of food and feed enzymes: status and prospectives. Enzyme Hum. Anim. Nutr. Elsevier. 487-514.

[26] Ho, C.R., Shylesh, S., Bell, A.T., 2016. Mechanism and kinetics of ethanol coupling to butanol over hydroxyapatite. ACS Catal. 6(2), 939948.

[27] Humbird, D., Davis, R., Tao, L., Kinchin, C., Hsu, D., Aden, A., Schoen, P., Lukas, J., Olthof, B., Worley, M., Sexton, D., Dudgeon, D., 2011. Process design and economics for biochemical conversion of lignocellulosic biomass to ethanol: dilute-acid pretreatment and enzymatic hydrolysis of corn stover. National Renew. Energy Lab. Golden, $\mathrm{CO}$ (United States).

[28] ICIS, 2016. Icis pricing [WWW Document]. Chem. price.

[29] Jafari, Y., Amiri, H., Karimi, K., 2016. Acetone pretreatment for improvement of acetone, butanol, and ethanol production from sweet sorghum bagasse. Appl. Energy. 168, 216-225.

[30] Jang, M.O., Choi, G., 2018. Techno-economic analysis of butanol production from lignocellulosic biomass by concentrated acid pretreatment and hydrolysis plus continuous fermentation. Biochem. Eng. J. 134, 30-43.

[31] Koda, K., Matsu-ura, T., Obora, Y., Ishii, Y., 2009. Guerbet reaction of ethanol to $n$-butanol catalyzed by iridium complexes. Chem. Lett. 38(8), 838-839.

[32] Kumar, M., Gayen, K., 2011. Developments in biobutanol production: new insights. Appl. Energy. 88(6), 1999-2012.
[33] Kumar Mahapatra, M., Kumar, A., 2017. A Short Review on biobutanol, a second generation biofuel production from lignocellulosic biomass. J. Clean Energy Technol. 5(1), 27-30.

[34] Kuo, C.H., Huang, C.Y., Shieh, C.J., Wang, H.M.D., Tseng, C.Y., 2019. Hydrolysis of orange peel with cellulase and pectinase to produce bacterial cellulose using Gluconacetobacter xylinus. Waste Biomass Valorization. 10(1), 85-93

[35] Lee, S.Y., Park, J.H., Jang, S.H., Nielsen, L.K., Kim, J., Jung, K.S., 2008. Fermentative butanol production by clostridia. Biotechnol Bioeng. 101(2), 209-228.

[36] León, M., Díaz, E., Ordóñez, S., 2011. Ethanol catalytic condensation over Mg-Al mixed oxides derived from hydrotalcites. Catal. Today. $164(1), 436-442$

[37] Li, J., Chen, X., Qi, B., Luo, J., Zhang, Y., Su, Y., Wan, Y., 2014 Efficient production of acetone-butanol-ethanol (ABE) from cassava by a fermentation-pervaporation coupled process. Bioresour Technol. 169, 251-257.

[38] Liu, G., Zhang, J., Bao, J., 2016. Cost evaluation of cellulase enzyme for industrial-scale cellulosic ethanol production based on rigorous Aspen Plus modeling. Bioprocess. Biosyst. Eng. 39(1), 133-140.

[39] Lu, C., Dong, J., Yang, S.T., 2013. Butanol production from wood pulping hydrolysate in an integrated fermentation-gas stripping process. Bioresour. Technol. 143, 467-475.

[40] Marcu, I.C., Tanchoux, N., Fajula, F., Tichit, D., 2013. Catalytic conversion of ethanol into butanol over $\mathrm{M}-\mathrm{Mg}$ - $\mathrm{Al}$ mixed oxide catalysts $(\mathrm{M}=\mathrm{Pd}, \mathrm{Ag}, \mathrm{Mn}, \mathrm{Fe}, \mathrm{Cu}, \mathrm{Sm}, \mathrm{Yb})$ obtained from $\mathrm{LDH}$ precursors. Catal. Lett. 143(1), 23-30.

[41] Marcu, I.C., Tichit, D., Fajula, F., Tanchoux, N., 2009. Catalytic valorization of bioethanol over $\mathrm{Cu}-\mathrm{Mg}$ - $\mathrm{Al}$ mixed oxide catalysts. Catal. Today. 147(3-4), 231-238.

[42] Mariano, A.P., Dias, M.O.S., Junqueira, T.L., Cunha, M.P., Bonomi, A., Filho, R.M., 2013. Butanol production in a first-generation Brazilian sugarcane biorefinery: technical aspects and economics of greenfield projects. Bioresour. Technol. 135, 316-323.

[43] Markets, M., 2016. N-butanol market: global trends and forecasts to 2018 by applications (butyl acrylate, butyl acetate, glycol ethers, and others) and geography, report $\mathrm{CH} 1543$.

[44] Mazzoni, R., Cesari, C., Zanotti, V., Lucarelli, C., Tabanelli, T. Puzzo, F., Passarini, F., Neri, E., Marani, G., Prati, R., Viganò, F., Conversano, A., Cavani, F., 2019. Catalytic biorefining of ethanol from wine waste to butanol and higher alcohols: modeling the life cycle assessment and process design. ACS Sust. Chem. Eng. 7(1), 224-237.

[45] Mohapatra, S., Mishra, R.R., Nayak, B., Behera, B.C., Mohapatra, P.K.D., 2020. Development of co-culture yeast fermentation for efficient production of biobutanol from rice straw: A useful insight in valorization of agro industrial residues. Bioresour. Technol. 318, 124070 .

[46] Moncada, J., Tamayo, J., Cardona, C.A., 2014. Evolution from biofuels to integrated biorefineries: techno-economic and environmental assessment of oil palm in Colombia. J. Clean. Prod. $81,51-59$

[47] Moncada, J., Tamayo, J.A., Cardona, C.A., 2016. Techno-economic and environmental assessment of essential oil extraction from Oregano (Origanum vulgare) and Rosemary (Rosmarinus officinalis) in Colombia. J. Clean. Prod. 112, 172-181.

[48] Mussatto, S.I., Moncada, J., Roberto, I.C., Cardona, C.A., 2013. Techno-economic analysis for brewer's spent grains use on a biorefinery concept: the Brazilian case. Bioresour. Technol. 148 , $302-310$

[49] Naleli, K., 2016. Process modeling in production of biobutanol from lignocellulosic biomass via ABE fermentation. Doctoral dissertation, Stellenbosch: Stellenbosch University. 63-66.

[50] Ndaba, B., Chiyanzu, I., Marx, S., 2015. n-Butanol derived from biochemical and chemical routes: a review. Biotechnol. Rep. 8, 1-9.

[51] Nezam, I., Peereboom, L., Miller, D.J., 2019. Continuous condensedphase ethanol conversion to higher alcohols: experimental results and techno-economic analysis. J. Clean. Prod. 209, 1365-1375. 
[52] Ogo, S., Onda, A., Yanagisawa, K., 2011. Selective synthesis of 1 butanol from ethanol over strontium phosphate hydroxyapatite catalysts. Appl. Catal., A. 402(1-2), 188-195.

[53] Ortiz-Sanchez, M., Solarte-Toro, J.C., Orrego-Alzate, C.E., AcostaMedina, C.D., Cardona-Alzate, C.A., 2020. Integral use of orange peel waste through the biorefinery concept: an experimental, technical, energy, and economic assessment. Biomass Convers. Biorefinery. 1-15.

[54] Ortiz, D.L., Batuecas, E., Orrego, C.E., Rodríguez, L.J., Camelin, E., Fino, D., 2020. Sustainable management of peel waste in the small-scale orange juice industries: a Colombian case study. J. Clean. Prod. 265, 121587.

[55] Peters, M.S., Timmerhaus, K.D., West, R.E., 2003. Plant design and economics for chemical engineers, fifth ed. New York, McGraw-Hill.

[56] Pourbafrani, M., Forgács, G., Horváth, I.S., Niklasson, C., Taherzadeh, M.J., 2010. Production of biofuels, limonene, and pectin from citrus wastes. Bioresour. Technol. 101(11), 4246-4250.

[57] Pourbafrani, M., Talebnia, F., Niklasson, C., Taherzadeh, M.J., 2007. Protective effect of encapsulation in fermentation of limonene-contained media and orange peel hydrolyzate. Int. J. Mol. Sci. 8(8), 777-787.

[58] Prausnitz, J.M., Lichtenthaler, R.N., De Azevedo, E.G.,1999. Molecular thermodynamics of fluid-phase equilibria, Third ed. Prentice-Hall PTR.

[59] Quintero, J.A., Cardona, C.A., 2011. Process simulation of fuel ethanol production from lignocellulosics using aspen plus. Ind. Eng. Chem. Res. 50(10), 6205-6212.

[60] Quintero, J.A., Moncada, J., Cardona, C.A., 2013. Techno-economic analysis of bioethanol production from lignocellulosic residues in Colombia: a process simulation approach. Bioresour. Technol. 139, 300307.

[61] Qureshi, N., Saha, B.C., Cotta, M.A., 2007. Butanol production from wheat straw hydrolysate using Clostridium beijerinckii. Bioprocess. Biosyst. Eng. 30(6), 419-427.

[62] Qureshi, N., Saha, B.C., Cotta, M.A., Singh, V., 2013. An economic evaluation of biological conversion of wheat straw to butanol: a biofuel. Energy Convers. Manage. 65, 456-462.

[63] Riittonen, T., Toukoniitty, E., Madnani, D.K., Leino, A.R., Kordas, K., Szabo, M., Sapi, A., Arve, K., Wärnå, J., Mikkola, J.P., 2012. One-pot liquid-phase catalytic conversion of ethanol to 1-butanol over aluminium oxide-the effect of the active metal on the selectivity. Catalysts. 2(1), 6884.

[64] Rincón, L.E., Becerra, L.A., Moncada, J., Cardona, C.A., 2014. Technoeconomic analysis of the use of fired cogeneration systems based on sugar cane bagasse in southeastern and mid-western regions of Mexico. Waste Biomass Valorization. 5, 189-198.

[65] Salehi Jouzani, G., Taherzadeh, M.J., 2015. Advances in consolidated bioprocessing systems for bioethanol and butanol production from biomass: a comprehensive review. Biofuel Res. J. 5, 152-195.

[66] Serna-Loaiza, S., Carmona-Garcia, E., Cardona, C.A., 2018. Potential raw materials for biorefineries to ensure food security: the Cocoyam case. Ind. Crops Prod. 126, 92-102.

[67] Solarte-Toro, J.C., Chacón-Pérez, Y., Piedrahita-Rodríguez, S., Giraldo, J.A.P., Teixeira, J.A., Moustakas, K., Alzate, C.A.C., 2020. Effect of dilute sulfuric acid pretreatment on the physicochemical properties and enzymatic hydrolysis of coffee cut-stems. Energy. 195.
[68] Solarte-Toro, J.C., Romero-García, J.M., Martínez-Patiño, J.C., Ruiz-Ramos, E., Castro-Galiano, E., Cardona-Alzate, C.A., 2019 Acid pretreatment of lignocellulosic biomass for energy vectors production: a review focused on operational conditions and technoeconomic assessment for bioethanol production. Renew. Sust. Energy Rev. 107, 587-601.

[69] Sun, Z., Liu, S., 2012. Production of n-butanol from concentrated sugar maple hemicellulosic hydrolysate by Clostridia acetobutylicum ATCC824. Biomass Bioenergy. 39, 39-47.

[70] Talebnia, F., Bafrani, M.P., Lundin, M., Taherzadeh, M., 2008 Optimization study of citrus wastes saccharification by dilute-acid hydrolysis. BioResources. 3(1), 108-122.

[71] Tao, L., He, X., Tan, E.C.D., Zhang, M., Aden, A., 2014. Comparative techno-economic analysis and reviews of $\mathrm{n}$-butano production from corn grain and corn stover. Biofuels, Bioprod. Biorefining. 8(3), 342-361.

[72] Tomás-Pejó, E., Oliva, J.M., Ballesteros, M., Olsson, L., 2008. Comparison of SHF and SSF processes from steam-exploded whea straw for ethanol production by xylose-fermenting and robust glucose-fermenting Saccharomyces cerevisiae strains. Biotechnol. Bioeng. 100(6), 1122-1131

[73] Tsuchida, T., Sakuma, S., Takeguchi, T., Ueda, W., 2006. Direct synthesis of $n$-butanol from ethanol over nonstoichiometric hydroxyapatite. Ind. Eng. Chem. Res. 45(25), 8634-8642.

[74] Ulrich, G.D., Vasudevan, P.T., 2006. How to estimate utility costs. Chem. Eng. 113(4), 66-69.

[75] Wilkins, M.R., Widmer, W.W., Grohmann, K., 2007. Simultaneous saccharification and fermentation of citrus peel waste by Saccharomyces cerevisiae to produce ethanol. Process Biochem. 42(12), 1614-1619.

[76] Wooley, R.J., Putsche, V., 1996. Development of an Aspen Plus property database for biofuels components. National Renew. Energy Lab. Golden, CO United States.

[77] Xin, F., Wu, Y.R., He, J., 2014. Simultaneous fermentation of glucose and xylose to butanol by Clostridium sp. strain BOH3. Appl. Environ. Microbiol. 80(15), 4771-4778

[78] Young, D., Scharp, R., Cabezas, H., 2000. The waste reduction (WAR) algorithm: environmental impacts, energy consumption, and engineering economics. Waste Manage. 20(8), 605-615.

[79] Zhou, W., Widmer, W., Grohmann, K., 2008. Developments in ethanol production from citrus peel waste. Proc. Florida State Hortic Soc. 121, 307-310.

[80] Zhou, W., Widmer, W., Grohmann, K., 2007. Economic analysis of ethanol production from citrus peel waste. Proc. Florida State Hortic. Soc. 120, 310-315

[81] Zhu, L., Cheung, C.S., Zhang, W.G., Huang, Z., 2010. Emissions characteristics of a diesel engine operating on biodiesel and biodiesel blended with ethanol and methanol. Sci. Total Environ. 408(4), 914 921. 


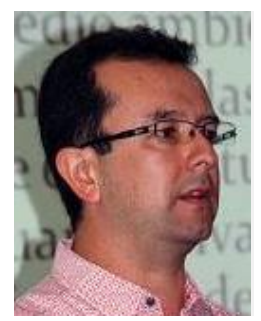

Carlos Ariel Cardona Alzate (Ch.E., MSc., Ph.D.) is a full professor of Chemical Engineering at Universidad Nacional de Colombia sede Manizales (Manizales, Colombia). His research interests include developing non-conventional separation processes, thermodynamics, process engineering, biorefineries, climate change, biotechnological processes, biofuels production, fermentation technology, and agroindustry. Dr. Cardona has collaborated in several international projects concerning chemical and biochemical process design, biofuels production using agricultural residues, and supporting economic development strategies, including bio-based resources. In addition, Prof. Cardona is recognized as a Senior researcher in Colombia because he has authored and co-authored 260 (according to Scopus) and 450 (according to Google Scholar) publications, 12 research books, and 46 book chapters. He has an h-index of 36 according to Scopus Moreover, Dr. Cardona has participated in international research projects with the UN-FAO, and EU member states.

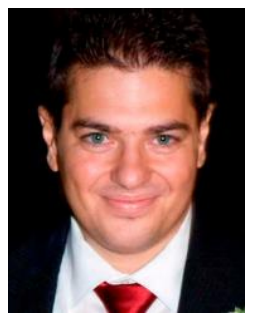

Konstantinos Moustakas has a Ph.D. in Chemical Engineering and is a renowned researcher in the field of waste management. Konstantinos is a Senior Researcher-Project Manager and a full professor at the National Technical University of Athens, School of Engineering, Unit of Environment Science \& Technology (UEST). Dr. Konstantinos Moustakas has participated in more than 60 projects in more than 15 countries (2000-2018). Moreover, he has considerable international experience working in EU-funded projects in several EU member states in different capacities as a technical expert, researcher, short-term expert, project management expert, training expert, and dissemination expert. Dr. Konstantinos Moustakas has published more than 120 research papers and has an h-index of 21, according to Scopus. $\mathrm{He}$ is also the head of the organizing committee of the Conference Series on Sustainable Solid Waste Management.

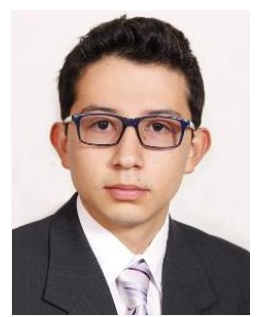

Juan Camilo Solarte-Toro (Ch.E., MSc.) is a Ph.D. candidate in Chemical Engineering at Universidad Nacional de Colombia sede Manizales. His research interests include energy vector production, biotechnological and thermochemical biomass upgrading, heterogeneous catalysis applied to biomass conversion, and design, simulation, and analysis of biorefineries considering technical, energy, economic, environmental, and social aspects. Solarte-Toro has worked on evaluating biogas production using agroindustrial waste, decentralized production of syngas and electricity by biomass gasification, and integral assessment of biorefineries towards more sustainable processes. Solarte-Toro is recognized as a Junior researcher in Colombia because of the publication of 23 research papers and 5 book chapters in collaboration with the Chemical, Catalytic, and Biotechnological Processes research group led by Professor Carlos Ariel Cardona Alzate. Finally, He has an h-index of 8 (Scopus).

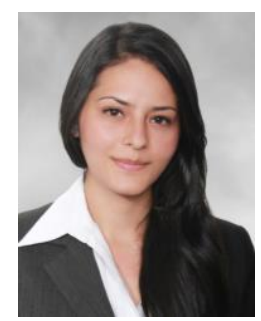

Estefanny Carmona-García (Ch.E., MSc.) is a researcher in energy vector production, biotechnological conversion of biomass to biofuels, pretreatment technologies, design and simulation of biorefineries, and techno-economic and environmental assessment of the related processes. More specifically, Carmona-García has worked on evaluating biogas production using agro-industrial waste and biobutanol production using lignocellulosic biomass. Moreover, she has participated in international research projects for the development of smallscale biorefineries in developed and developing countries. Currently, Carmona-García is working in the private sector focused on research and development. Carmona-García has published 5 research papers in collaboration with the Chemical, Catalytic, and Biotechnological Processes research group led by Professor Carlos Ariel Cardona Alzate. She has an hindex of 4 (Scopus).

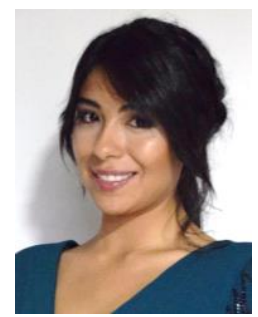

Paula Andrea Marín-Valencia (Ch.E., MSc.)`s research interests include extraction of bioactive compounds, supercritical fluid extraction, measurement of antioxidant capacity, aromatic plants, design and simulation of biorefineries, and techno-economic and environmental assessment of related processes. Marín-Valencia has worked on extracting phenolic compounds and antioxidants from aromatic plants such as Marigold (Calendula officinalis) and Thyme (Thymus vulgaris). She has also worked on the application of antioxidants as additives in polymers. Moreover, Marín-Valencia has participated in national research projects aimed at finding pathways for aromatic plant residues valorization Currently, Marín-Valencia is working in the private sector focused on research and development. She has published 2 research papers in collaboration with the Chemical, Catalytic, and Biotechnological Processes research group led by Professor Carlos Ariel Cardona Alzate. 


\section{Supplementary Data}

\section{Appendix 1}

Reactions proposed by Tsuchida et al. (2006) (Eqs. S1-S13).

$$
2 \mathrm{C}_{2} \mathrm{H}_{5} \mathrm{OH} \stackrel{\mathrm{k}_{1}}{\rightarrow} \mathrm{C}_{4} \mathrm{H}_{9} \mathrm{OH}+\mathrm{H}_{2} \mathrm{O}
$$

2 Ethanol $\rightarrow$ Butanol + Water

$$
\mathrm{C}_{2} \mathrm{H}_{5} \mathrm{OH}+\mathrm{C}_{4} \mathrm{H}_{9} \mathrm{OH} \stackrel{\mathrm{k}_{2}}{\rightarrow} \mathrm{C}_{6} \mathrm{H}_{13} \mathrm{OH}+\mathrm{H}_{2} \mathrm{O}
$$

Ethanol + Butanol $\rightarrow$ Hexanol + Water

$$
\mathrm{C}_{2} \mathrm{H}_{5} \mathrm{OH}+\mathrm{C}_{4} \mathrm{H}_{9} \mathrm{OH} \stackrel{\mathrm{k}_{3}}{\rightarrow} \mathrm{C}_{2} \mathrm{H}_{5} \mathrm{CH}\left(\mathrm{C}_{2} \mathrm{H}_{5}\right) \mathrm{CH}_{2} \mathrm{OH}+\mathrm{H}_{2} \mathrm{O}
$$

Ethanol + Butanol $\rightarrow$ 2-ethyl-1-butanol + Water

$$
\mathrm{C}_{2} \mathrm{H}_{5} \mathrm{OH}+\mathrm{C}_{6} \mathrm{H}_{13} \mathrm{OH} \stackrel{\mathrm{k}_{4}}{\rightarrow} \mathrm{C}_{8} \mathrm{H}_{17} \mathrm{OH}+\mathrm{H}_{2} \mathrm{O}
$$

Ethanol + Hexanol $\rightarrow$ Octanol + Water

$$
\mathrm{C}_{2} \mathrm{H}_{5} \mathrm{OH}+\mathrm{C}_{6} \mathrm{H}_{13} \mathrm{OH} \stackrel{\mathrm{k}_{5}}{\rightarrow} \mathrm{C}_{4} \mathrm{H}_{9} \mathrm{CH}\left(\mathrm{C}_{2} \mathrm{H}_{5}\right) \mathrm{CH}_{2} \mathrm{OH}+\mathrm{H}_{2} \mathrm{O}
$$

Ethanol + Hexanol $\rightarrow$ 2-ethyl-1-hexanol + Water

$$
\mathrm{C}_{2} \mathrm{H}_{5} \mathrm{OH} \stackrel{\mathrm{k}_{6}}{\rightarrow} \mathrm{C}_{2} \mathrm{H}_{4}+\mathrm{H}_{2} \mathrm{O}
$$

Ethanol $\rightarrow$ Ethylene + Water

$$
\mathrm{C}_{4} \mathrm{H}_{9} \mathrm{OH} \stackrel{\mathrm{k}_{7}}{\rightarrow} \mathrm{C}_{4} \mathrm{H}_{8}+\mathrm{H}_{2} \mathrm{O}
$$

Ethanol $\rightarrow$ Butene + Water

$$
\mathrm{C}_{6} \mathrm{H}_{13} \mathrm{OH} \stackrel{\mathrm{k}_{8}}{\rightarrow} \mathrm{C}_{6} \mathrm{H}_{12}+\mathrm{H}_{2} \mathrm{O}
$$

Hexenol $\rightarrow$ Hexene + Water

$$
\mathrm{C}_{8} \mathrm{H}_{17} \mathrm{OH} \stackrel{\mathrm{k}_{9}}{\rightarrow} \mathrm{C}_{8} \mathrm{H}_{16}+\mathrm{H}_{2} \mathrm{O}
$$

Octanol $\rightarrow$ Octene + Water

$$
\mathrm{C}_{2} \mathrm{H}_{5} \mathrm{OH} \stackrel{\mathrm{k}_{10}}{\rightarrow} \mathrm{CH}_{3} \mathrm{CHO}+\mathrm{H}_{2}
$$

Ethanol $\rightarrow$ Acetaldehyde + Hydrogen

$$
2 \mathrm{C}_{2} \mathrm{H}_{5} \mathrm{OH}+\mathrm{CH}_{3} \mathrm{CHO} \stackrel{\mathrm{k}_{11}}{\rightarrow} \mathrm{CH}_{2}=\mathrm{CHCH}=\mathrm{CH}_{2}+2 \mathrm{H}_{2} \mathrm{O}+\mathrm{H}_{2}+\mathrm{CH}_{3} \mathrm{CHO}
$$

2 Ethanol + Acetaldehyde $\rightarrow$ 1,3-butadiene +2 Water + Hydrogen + Acetaldehyde

$$
\mathrm{C}_{2} \mathrm{H}_{5} \mathrm{OH} \stackrel{\mathrm{k}_{12}}{\rightarrow} \text { Aromatics }
$$

Ethanol $\rightarrow$ Aromatics

$$
\mathrm{C}_{2} \mathrm{H}_{5} \mathrm{OH} \stackrel{\mathrm{k}_{13}}{\rightarrow} \text { Others }
$$

Ethanol $\rightarrow$ Others 


\section{Appendix 2}

Reaction rate equations proposed by Tsuchida et al. (2006) (Eqs. S14-S27).

$\frac{\mathrm{d}[\mathrm{EtOH}]}{\mathrm{dt}}=-2 \mathrm{k}_{1}[\mathrm{EtOH}]^{2}-\left(\mathrm{k}_{2}+\mathrm{k}_{3}\right)[\mathrm{EtOH}][\mathrm{ButOH}]-\left(\mathrm{k}_{4}+\mathrm{k}_{5}\right)[\mathrm{EtOH}][\mathrm{HexOH}]-\left(\mathrm{k}_{6}+\mathrm{k}_{10}+\mathrm{k}_{13}\right)[\mathrm{EtOH}]-2 \mathrm{k}_{11}[$ EtOH $][$ Acetal $]$

$\frac{\mathrm{d}[\mathrm{ButOH}]}{\mathrm{dt}}=\mathrm{k}_{1}[\mathrm{EtOH}]^{2}-\left(\mathrm{k}_{2}+\mathrm{k}_{3}\right)[\mathrm{EtOH}][\mathrm{ButOH}]-\mathrm{k}_{7}[\mathrm{ButOH}]$

$\frac{\mathrm{d}[\mathrm{HexOH}]}{\mathrm{dt}}=\mathrm{k}_{2}[\mathrm{EtOH}][\mathrm{ButOH}]-\left(\mathrm{k}_{4}+\mathrm{k}_{5}\right)[\mathrm{EtOH}][\mathrm{HexOH}]-\mathrm{k}_{8}[\mathrm{HexOH}]$

$\frac{\mathrm{d}[\mathrm{EtButOH}]}{\mathrm{dt}}=\mathrm{k}_{3}[\mathrm{EtOH}][\mathrm{ButOH}]$

$\frac{\mathrm{d}[\mathrm{OctOH}]}{\mathrm{dt}}=\mathrm{k}_{4}[\mathrm{EtOH}][\mathrm{HexOH}]-\mathrm{k}_{9}[\mathrm{OctOH}]$

$\frac{\mathrm{d}[\mathrm{EtHexOH}]}{\mathrm{dt}}=\mathrm{k}_{5}[\mathrm{EtOH}][\mathrm{HexOH}]$

$\frac{\mathrm{d}[\text { Ethy }]}{\mathrm{dt}}=\mathrm{k}_{6}[\mathrm{EtOH}]$

$\frac{\mathrm{d}[\text { Bute }]}{\mathrm{dt}}=\mathrm{k}_{7}[\mathrm{ButOH}]$

$\frac{\mathrm{d}[\text { Hexe }]}{\mathrm{dt}}=\mathrm{k}_{8}[\mathrm{HexOH}]$

$\frac{\mathrm{d}[\mathrm{Octe}]}{\mathrm{dt}}=\mathrm{k}_{9}[\mathrm{OctOH}]$

$\frac{\mathrm{d}[\text { Acetal }]}{\mathrm{dt}}=\mathrm{k}_{10}[\mathrm{EtOH}]$

$\frac{\mathrm{d}[\text { Butadi }]}{\mathrm{dt}}=\mathrm{k}_{11}[$ EtOH $][$ Acetal $]$

$\frac{\mathrm{d}[\text { Aromatics }]}{\mathrm{dt}}=\mathrm{k}_{12}[\mathrm{EtOH}]$

$\frac{\mathrm{d}[\text { Others }]}{\mathrm{dt}}=\mathrm{k}_{13}[\mathrm{EtOH}]$

$\mathrm{k}_{1}-\mathrm{k}_{13}$ are the reaction constants for each reaction step, which was calculated using the Arrhenius equation (Eq. S28).

$\mathrm{k}_{\mathrm{i}}(\mathrm{T})=\mathrm{A}_{\mathrm{o}} \exp \left(\frac{-\mathrm{E}_{\mathrm{ai}}}{\mathrm{RT}}\right)$

where: Ao is pre-exponential factor, $\mathrm{T}$ temperature, $\mathrm{E}_{\mathrm{ai}}$ Activation energy, and $\mathrm{R}$ ideal gas constant. 